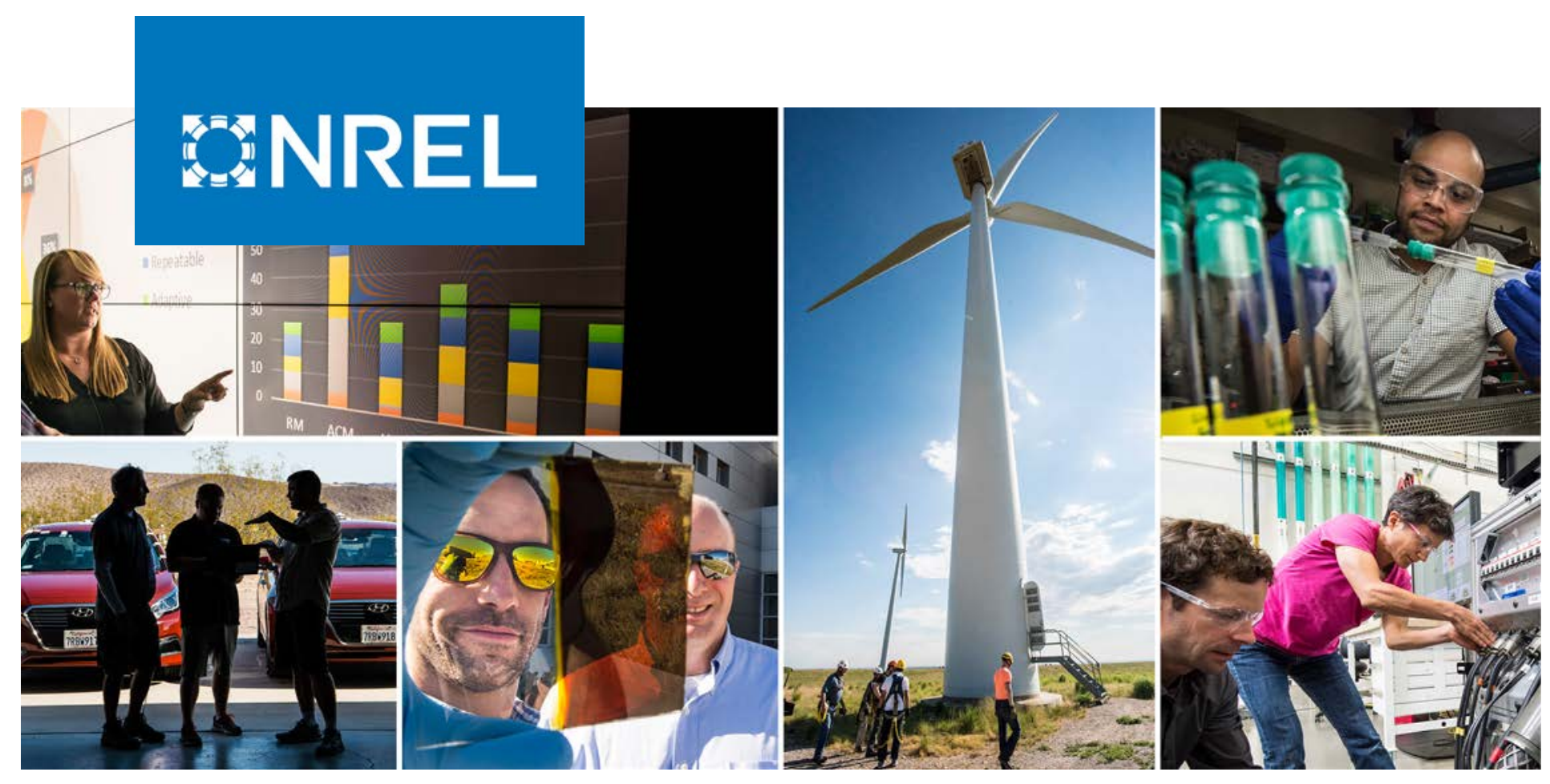

\title{
Policy and Regulatory Environment for Utility-Scale Energy Storage: Nepal
}

Amy Rose, Kapil Duwadi, David Palchak, and Mohit Joshi

National Renewable Energy Laboratory

Produced under direction of U.S. Department of State by the National Renewable Energy Laboratory (NREL) under Interagency Agreement No. IAG-17-02055.

NREL is a national laboratory of the U.S. Department of Energy Office of Energy Efficiency \& Renewable Energy

Operated by the Alliance for Sustainable Energy, LLC

This report is available at no cost from the National Renewable Energy Laboratory (NREL) at www.nrel.gov/publications.
Strategic Partnership Project Report NREL/TP-5C00-80591

September 2021 


\title{
GNREL
}

\section{Policy and Regulatory Environment for Utility-Scale Energy Storage: Nepal}

\author{
Amy Rose, Kapil Duwadi, David Palchak, and Mohit Joshi \\ National Renewable Energy Laboratory
}

\section{Suggested Citation}

Rose, Amy, Kapil Duwadi, David Palchak, and Mohit Joshi. 2021. Policy and Regulatory Environment for Utility-Scale Energy Storage: Nepal. Golden, CO: National Renewable Energy Laboratory. NREL/TP-5C00-80591. https://www.nrel.gov/docs/fy21osti/80591.pdf.

NREL is a national laboratory of the U.S. Department of Energy Office of Energy Efficiency \& Renewable Energy Operated by the Alliance for Sustainable Energy, LLC

This report is available at no cost from the National Renewable Energy Laboratory (NREL) at www.nrel.gov/publications.

Contract No. DE-AC36-08GO28308
Strategic Partnership Project Report NREL/TP-5C00-80591

September 2021

National Renewable Energy Laboratory 15013 Denver West Parkway Golden, CO 80401 303-275-3000 • www.nrel.gov 


\section{NOTICE}

This work was authored by the National Renewable Energy Laboratory, operated by Alliance for Sustainable Energy, LLC, for the U.S. Department of Energy (DOE) under Contract No. DE-AC36-08GO28308. Support for the work was also provided by the U.S. Department of State under Agreement No. IAG-17-02055. The views expressed in the article do not necessarily represent the views of the DOE or the U.S. Government. The U.S. Government retains and the publisher, by accepting the article for publication, acknowledges that the U.S. Government retains a nonexclusive, paid-up, irrevocable, worldwide license to publish or reproduce the published form of this work, or allow others to do so, for U.S. Government purposes.

This report is available at no cost from the National Renewable Energy Laboratory (NREL) at www.nrel.gov/publications.

U.S. Department of Energy (DOE) reports produced after 1991 and a growing number of pre-1991 documents are available free via www.OSTI.gov.

Cover Photos by Dennis Schroeder: (clockwise, left to right) NREL 51934, NREL 45897, NREL 42160, NREL 45891, NREL 48097, NREL 46526.

NREL prints on paper that contains recycled content. 


\section{Preface}

This report-Policy and Regulatory Environment for Utility-Scale Energy Storage: Nepal—is part of a series investigating the potential for utility-scale energy storage in South Asia. This report, focused on Nepal, is the third in a series of country-specific evaluations of policy and regulatory environments for energy storage in the region. These evaluations apply the previously developed Energy Storage Readiness Assessment to evaluate the policy and regulatory environment for energy storage in each country and provide insights into the opportunities and barriers related to energy storage growth and deployment. Previous evaluations have applied this framework to India and Bangladesh.

Each of these policy and regulatory evaluations of countries in South Asia includes a complementary techno-economic analysis focused on better understanding the drivers of energy storage investments in the region. Using NREL's power system planning and operational models of South Asia, these analyses identify potential storage applications and growth opportunities under various cost, policy, and demand growth scenarios. In addition, the regulatory and policy barriers and incentive mechanisms identified in the Energy Storage Readiness Assessments are incorporated into the modeling to enhance understanding of how they impact energy storage deployment and operation.

Together these studies will inform the applications and value of energy storage for power systems in South Asia, and policy and regulatory pathways to realize this value. The results of these collaborations are available at https://www.nrel.gov/international/energy-storage-southasia.html. 


\section{Acknowledgments}

The authors are greatly indebted to several individuals for their thoughtful feedback and guidance, including Ram Prasad Dhital (Nepal Electricity Regulatory Commission) as well as David Hurlbut and Venkat Durvasulu (NREL) for their reviews. Karen Petersen provided editorial assistance. Any errors and omissions are solely the responsibility of the authors. This work was funded by the U.S. Department of State, Bureau of Energy Resources. 


\section{List of Acronyms}

CDP

ERC

Corporate Development Plan

FERC

Electricity Regulatory Commission

FTM

Federal Energy Regulatory Commission

GoN

IPP

front-of-the-meter

Government of Nepal

independent power producer

IPPAN

$\mathrm{kWh}$

Independent Power Producers' Association, Nepal

MWh

kilowatt-hour

megawatt-hour

NEA

NPR

NREL

Nepal Electricity Authority

Nepalese rupee

National Renewable Energy Laboratory

NYSERDA

PROR

$\mathrm{PSH}$

PV

New York State Energy Research and Development Authority

peaking run-of-river

pumped storage hydropower

ROR

photovoltaic

run-of-river 


\section{Executive Summary}

Recent structural reforms to Nepal's electric power sector are raising ambitions for the country to achieve a reliable, affordable electricity supply. The planned development of Nepal's hydropower resources will enable the country to become a net exporter of electricity to neighboring countries, reducing the country's reliance on thermal-based imports to meet its energy needs. However, the expansion of hydropower - mostly run-of-river (ROR) plantsposes new challenges to maintain the balance of supply and demand and system adequacy due to the daily and seasonal fluctuations in supply. Energy storage has the potential to help meet these challenges by managing fluctuations in electricity supply and maximizing the use of Nepal's domestic hydropower.

The potential for storage to meet these needs depends on many factors, including physical characteristics of the power system and the policy and regulatory environments in which these investments would operate. This report applies an Energy Storage Readiness Assessment ${ }^{1}$ the National Renewable Energy Laboratory developed for policy makers and regulators to identify priority areas of focus as they continue to develop the appropriate suite of policies, programs, and regulations to enable storage deployment. This assessment uses a simple evaluation scheme (Figure ES-1) to identify the barriers and opportunities for utility-scale energy storage within Nepal's policy and regulatory environment.

\section{Status}

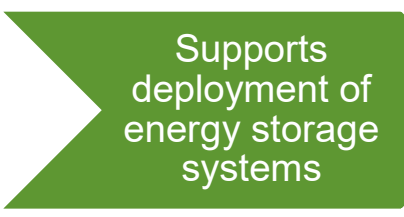

Moderate to no

impact on energy

storage systems
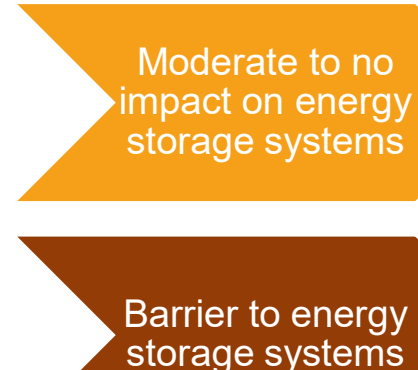

Grade

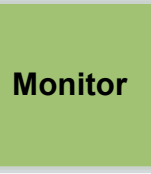

Review

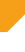

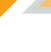
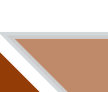

\section{(1)}

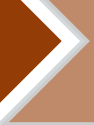

Revise

Existing system conditions may prevent energy storage investments: revisions may be needed to remove barriers $^{a}$

Existing system conditions have limited impact on energy storage deployment: review to better align with storage investments.

Existing system conditions (technical or nontechnical) support energy storage deployment: monitor and review these conditions to continually improve.

\section{Description}

\section{Figure ES-1. Evaluation scheme for Energy Storage Readiness Assessment}

a Revisions may not be recommended for system characteristics where conditions that are good for the overall system (i.e., high levels of system flexibility and reliability) may not support energy storage investments.

Table ES-1 summarizes the results of the Energy Storage Readiness Assessment for Nepal. In general, there are technical and economic opportunities for energy storage to provide peak

\footnotetext{
${ }^{1}$ For more information on the Energy Storage Readiness Assessment, see (Rose, Koebrich et al.2020).
} 
demand and ancillary services (green), and although the policy and regulatory frameworks are largely moderate (yellow) or unsupportive (red), this is largely due to an absence of storage considerations in current frameworks rather than poorly designed energy storage policies or rules.

Table ES-1. Results of Readiness Assessment for Nepal

\begin{tabular}{|c|c|c|c|c|}
\hline Topic & No. & Criteria & Assessment & Notes \\
\hline \multirow{7}{*}{$\begin{array}{c}\text { System } \\
\text { Characteristics }\end{array}$} & 1 & $\begin{array}{l}\text { Low or decreasing load factor in } \\
\text { electricity demand }\end{array}$ & & $\begin{array}{l}\text { Load factors are increasing } \\
\text { while peak demand is decreasing }\end{array}$ \\
\hline & 2 & $\begin{array}{l}\text { Inadequate or costly provision of } \\
\text { ancillary services }\end{array}$ & & $\begin{array}{l}\text { Energy storage could be a cost- } \\
\text { effective option to meet new } \\
\text { ancillary service requirements }\end{array}$ \\
\hline & 3 & $\begin{array}{l}\text { Inadequate or costly supply options } \\
\text { during peak demand periods }\end{array}$ & & $\begin{array}{l}\text { Storage is increasingly cost } \\
\text { competitive to meet peak } \\
\text { demand }\end{array}$ \\
\hline & 4 & $\begin{array}{l}\text { Increasing levels of transmission } \\
\text { congestion }\end{array}$ & & $\begin{array}{l}\text { Specific corridors experiencing } \\
\text { overloading }\end{array}$ \\
\hline & 5 & $\begin{array}{l}\text { Proposed network upgrades with low } \\
\text { anticipated utilization }\end{array}$ & & $\begin{array}{l}\text { Proposed upgrades anticipated to } \\
\text { have high utilization }\end{array}$ \\
\hline & 6 & Low flexibility in the generation mix & & $\begin{array}{l}\text { Maximum flexibility needs are } \\
\text { increasing, but these instances } \\
\text { are occurring less frequently }\end{array}$ \\
\hline & 7 & $\begin{array}{l}\text { Increasing curtailment of variable } \\
\text { renewable energy (VRE) }\end{array}$ & & $\begin{array}{l}\text { No curtailment of VRE to date; } \\
\text { storage could reduce curtailment } \\
\text { of run-of-river hydropower }\end{array}$ \\
\hline \multirow{6}{*}{ Policy } & 8 & $\begin{array}{l}\text { Inclusion of storage in energy policy } \\
\text { and master plan }\end{array}$ & & $\begin{array}{l}\text { No clear policy for energy } \\
\text { storage; plans focused on } \\
\text { pumped storage hydropower } \\
\text { (PSH) }\end{array}$ \\
\hline & 9 & Targets for storage deployment & & $\begin{array}{l}\text { No specific targets for utility- } \\
\text { scale storage; PSH included } \\
\text { among other technologies in } \\
\text { generation mix target }\end{array}$ \\
\hline & 10 & $\begin{array}{l}\text { Energy strategy promotes operational } \\
\text { flexibility }\end{array}$ & & $\begin{array}{l}\text { Recent initiatives focus on } \\
\text { flexibility, but opportunities for } \\
\text { storage are limited }\end{array}$ \\
\hline & 11 & $\begin{array}{l}\text { Support organized knowledge sharing } \\
\text { and delivery for scale-up and } \\
\text { replication }\end{array}$ & & $\begin{array}{l}\text { No initiatives or organizations } \\
\text { focused on promoting storage }\end{array}$ \\
\hline & 12 & $\begin{array}{l}\text { Domestic industrial policy supports } \\
\text { storage manufacturing }\end{array}$ & & $\begin{array}{l}\text { Energy sector among prioritized } \\
\text { sectors, but no specific } \\
\text { manufacturing programs }\end{array}$ \\
\hline & 13 & Targeted support to early adopters & & $\begin{array}{l}\text { Support focused on pilot PSH } \\
\text { projects }\end{array}$ \\
\hline \multirow{3}{*}{ Regulation } & 14 & $\begin{array}{l}\text { Utilities and private developers allowed } \\
\text { to make storage investments }\end{array}$ & & $\begin{array}{l}\text { For nonhydro storage, } \\
\text { development limited to hybrid } \\
\text { projects }\end{array}$ \\
\hline & 15 & $\begin{array}{l}\text { Interconnection processes give storage } \\
\text { the right to interconnect and obtain } \\
\text { transmission service }\end{array}$ & & $\begin{array}{l}\text { PSH or hybrid storage projects } \\
\text { can connect as generation assets }\end{array}$ \\
\hline & 16 & $\begin{array}{l}\text { Promotion of high-quality standardized } \\
\text { energy storage technologies through } \\
\text { safety standards }\end{array}$ & & $\begin{array}{l}\text { No safety standards in place or } \\
\text { underway }\end{array}$ \\
\hline
\end{tabular}




\begin{tabular}{|l|l|l|l|l|}
\hline Topic & No. & Criteria & Assessment & Notes \\
\hline & 17 & $\begin{array}{l}\text { Operating requirements for fast- } \\
\text { responding assets }\end{array}$ & $\begin{array}{l}\text { Only PSH can provide most } \\
\text { services }\end{array}$ \\
\cline { 2 - 4 } & 18 & $\begin{array}{l}\text { Electricity services charges reflect } \\
\text { value of and increase price } \\
\text { transparency for energy services }\end{array}$ & $\begin{array}{l}\text { Contract rates and consumer } \\
\text { tariffs include time of day and } \\
\text { seasonal components }\end{array}$ \\
\cline { 2 - 5 } & 19 & $\begin{array}{l}\text { Storage able to compete with other grid } \\
\text { assets to provide multiple services }\end{array}$ & $\begin{array}{l}\text { Opportunities limited to PSH or } \\
\text { hybrid projects }\end{array}$ \\
\cline { 2 - 5 } & 20 & $\begin{array}{l}\text { Storage able to receive revenue for } \\
\text { providing multiple services }\end{array}$ & $\begin{array}{l}\text { Compensation for services } \\
\text { beyond power is not available }\end{array}$ \\
\hline
\end{tabular}

Note: Green: supports storage deployment; Yellow: moderate to no impact on storage; Red: barrier to storage

The technical system characteristics of Nepal's power system are favorable for energy storage to reduce the cost of supply during peak demand periods and dry season months and improve system reliability. Nepal's energy policy framework does not articulate a clear vision for energy storage in the country. Existing public support for specific projects can inform the development of a clear policy framework for energy storage that addresses the many services storage can provide as well as the full range of storage technologies available. The establishment of an independent regulator is leading to a host of regulatory reforms in Nepal's electric power sector. However, existing and proposed regulations restrict storage - particularly nonhydro storagefrom providing services or earning revenue for those services. These rules present a barrier to identifying and maximizing the cost-effective value of storage investments.

As Nepal continues to expand its power sector, energy storage technologies can contribute to meet evolving system needs for flexibility and reliability. Comprehensive policy and regulatory frameworks can enable economically viable storage technologies to meet these needs. 


\section{Table of Contents}

1 Introduction and Background ............................................................................................. 1

1.1 Nepal's Expanding Energy Landscape....................................................................... 1

1.2 The Role of Energy Storage in Nepal's Energy Strategy .................................................... 2

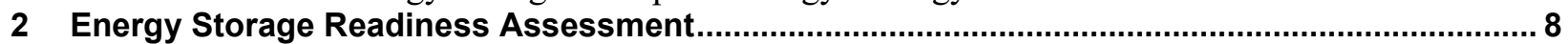

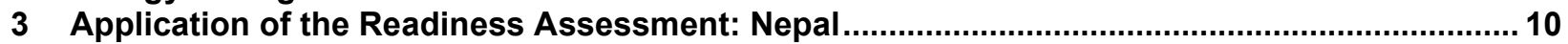

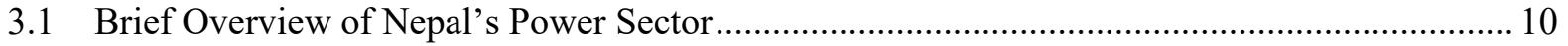

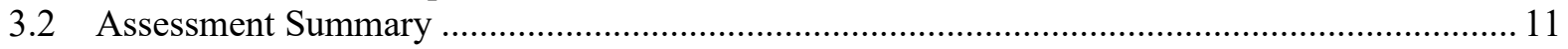

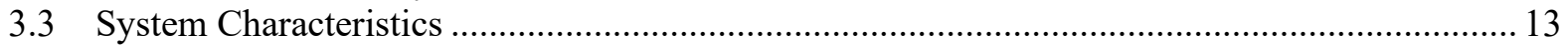

3.4 Policy 20

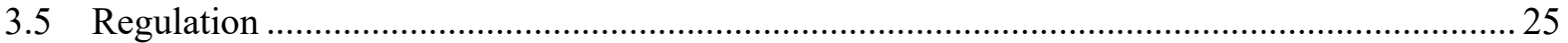

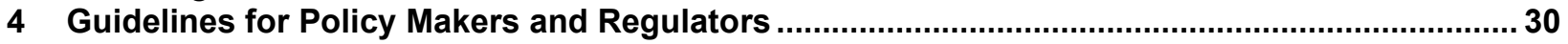

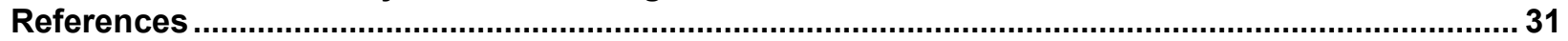




\section{List of Figures}

Figure ES-1. Evaluation scheme for Energy Storage Readiness Assessment...........................................vii

Figure 1. Evaluation scheme for Energy Storage Readiness Assessments .............................................. 9

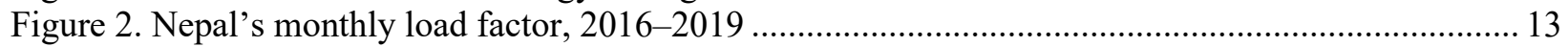

Figure 3. Change in hourly load profile on maximum demand day, FY 2016/17-FY 2019/20 ................ 14

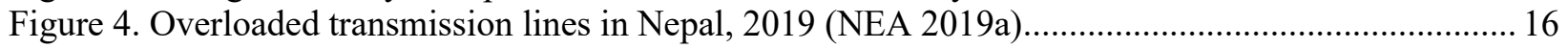

Figure 5. Box plot of historical per hour ramp-up, Nepal 2016-2020 ............................................. 18

Figure 6. Seasonal and time-of-day variation in electricity tariffs averaged for all eligible medium- and

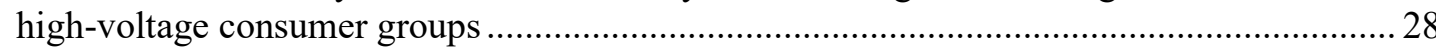

\section{List of Tables}

Table ES-1. Results of Readiness Assessment for Nepal .....................................................................viii

Table 1. Types of Services Energy Storage Can Provide at Bulk-System Level..................................... 4

Table 2. Components of the Energy Storage Readiness Assessment …................................................... 8

Table 3. Results of Readiness Assessment for Nepal .......................................................................... 12

Table 4. Change in Annual Nepal Exports to India with Incremental Energy Storage Additions............. 19

Table 5. Change in Generation Mix To Meet 2030 Policy Targets .........................................................2 21

Table 6. Fast Response Ancillary Services Under Development.............................................................. 27

Table 7. Seasonal and Time-of-Day PPA Rates (NPR per kWh) for Hydropower Plants......................... 28 


\section{Introduction and Background}

Recent structural reforms to Nepal's electric power sector are raising ambitions for the country to achieve a reliable, affordable electricity supply. The planned development of Nepal's hydropower resources will enable the country to become a net exporter of electricity to India, reducing the country's reliance on thermal-based imports to meet its electricity needs. However, the expansion of hydropower - mostly run-of-river (ROR) plants - poses new challenges to maintain the balance of supply and demand and system adequacy due to the daily and seasonal fluctuations in supply.

Energy storage has the potential to help meet these challenges by managing fluctuations in electricity supply and maximizing the use of Nepal's domestic hydropower. Declining costs for some energy storage technologies make energy storage an increasingly cost-effective option to meet these needs. However, the potential for energy storage deployment on the grid depends on many factors, including the physical characteristics of the power system and the policy and regulatory environments in which energy storage investments would operate.

This report was prepared by the National Renewable Energy Laboratory (NREL) with support from the U.S. Department of State to inform a broader dialogue around the future direction of Nepal's approach to enabling energy storage investments. This report applies an Energy Storage Readiness Assessment ${ }^{2}$ developed by NREL to assist policy makers and regulators in identifying priority areas for focus as they continue to develop the appropriate suite of policies, programs, and regulations to enable energy storage deployment.

This assessment aims to identify the barriers and opportunities for utility-scale energy storage within Nepal's policy and regulatory environment. As such, the report does not address applications for distributed energy storage ${ }^{3}$ (i.e., connected to the low- and medium-voltage networks), rural grid or stand-alone systems, or electric mobility. Importantly, the report does not inform whether energy storage is the best solution, among a wide range of possible technical and nontechnical interventions, to meet system needs.

\subsection{Nepal's Expanding Energy Landscape}

Nepal's electric power sector is undergoing dramatic reforms and expansion. In 2018, the Nepal Electricity Authority (NEA) ended a decade of load shedding due to supply shortages and, as of March 2020,90\% of the country's population of just under 30 million has access to electricity. Annual per capita electricity consumption has reached 264 kilowatt-hours (kWh), a 20\% increase over the preceding 3 years (Ministry of Finance 2020).

Despite this progress, Nepal's average per-capita electricity consumption is $60 \%$ lower than the South Asia regional average and one-tenth of the world average (IEA 2018). Nepal has ample

\footnotetext{
${ }^{2}$ For more information on the Readiness Assessment itself, see (Rose, Koebrich et al. 2020)

${ }^{3}$ See (Zinaman, Bowen, and Aznar 2020) for a detailed discussion of policy and regulatory design of distributed energy plus storage systems.
} 
natural resources to meet growing demand. Less than 5\% of the country's estimated 40,000 MW of economic hydropower potential has been developed for power generation (RPGCL 2018).

The Government of Nepal (GoN) has outlined several policy priorities to increase the country's electricity supply and stimulate growth in domestic electricity demand and supply (MOEWRI 2018a). Chief among these are goals to achieve $100 \%$ electricity access, increase annual percapita electricity consumption to $1,500 \mathrm{kWh}$, and reach 15,000 MW of hydropower capacity by 2028. To stimulate growth in domestic electricity consumption, the GoN has proposed industrial corridors and programs to promote the uptake of electric vehicles and electric cooking appliances.

On the supply side, the GoN is looking to accelerate the development of its hydropower resources for domestic consumption as well as for exports to neighboring countries. Most of the proposed hydropower additions are ROR and peaking ROR (PROR) plants, with only a few reservoir storage-type plants.

The combined changes of growth and diversification of electricity demand and the development of ROR and PROR hydropower plants pose new challenges for Nepal to maintain the balance of supply and demand and system adequacy. Because ROR plants do not store water, they cannot modulate their output to follow changes in daily electricity demand.

The proposed development of PROR plants, capable of storing water for a few hours of generation, will provide some intraday flexibility in the generation fleet. However, both technologies are subject to seasonal river flows. As a result, Nepal's hydro-based system experiences supply deficits during the dry months when it must import power from India to meet demand and surpluses during other parts of the year when excess water is wasted. To improve the use of the country's hydropower resources, the GoN is looking to improve cross-border trade with neighboring countries, particularly India.

These changes can meaningfully impact long-lasting investment and operational decisions for supply. Increased electricity demand presents opportunities for hydropower developers to increase return on investments through electricity sales. At the same time, as Nepal transitions from a position of deficit to surplus in electricity supply, inadequate flexibility to balance supply and demand on a daily and seasonal timescale may threaten these returns, and the overall economics of hydropower investments in Nepal, if excess hydropower resources cannot be used for domestic consumption or export during surplus periods.

Proposed projects located far from major load centers will require investments in dedicated transmission lines. For projects with large seasonal variation in their output, these lines may experience periods of high utilization and congestion followed by periods of very low utilization, raising new concerns about the techno-economic viability of new transmission investments.

\subsection{The Role of Energy Storage in Nepal's Energy Strategy}

Energy storage has the potential to help meet these challenges and accelerate Nepal's power sector expansion. Previous analyses of energy storage have identified several potential 
applications for storage at the bulk system level. Table 1 shows the range of services identified and the timescale at which these services would be provided. ${ }^{4}$

${ }^{4}$ For further discussion on the services energy storage can provide at the bulk system level, see (Rose, Koebrich et al. 2020). 
Table 1. Types of Services Energy Storage Can Provide at Bulk-System Level

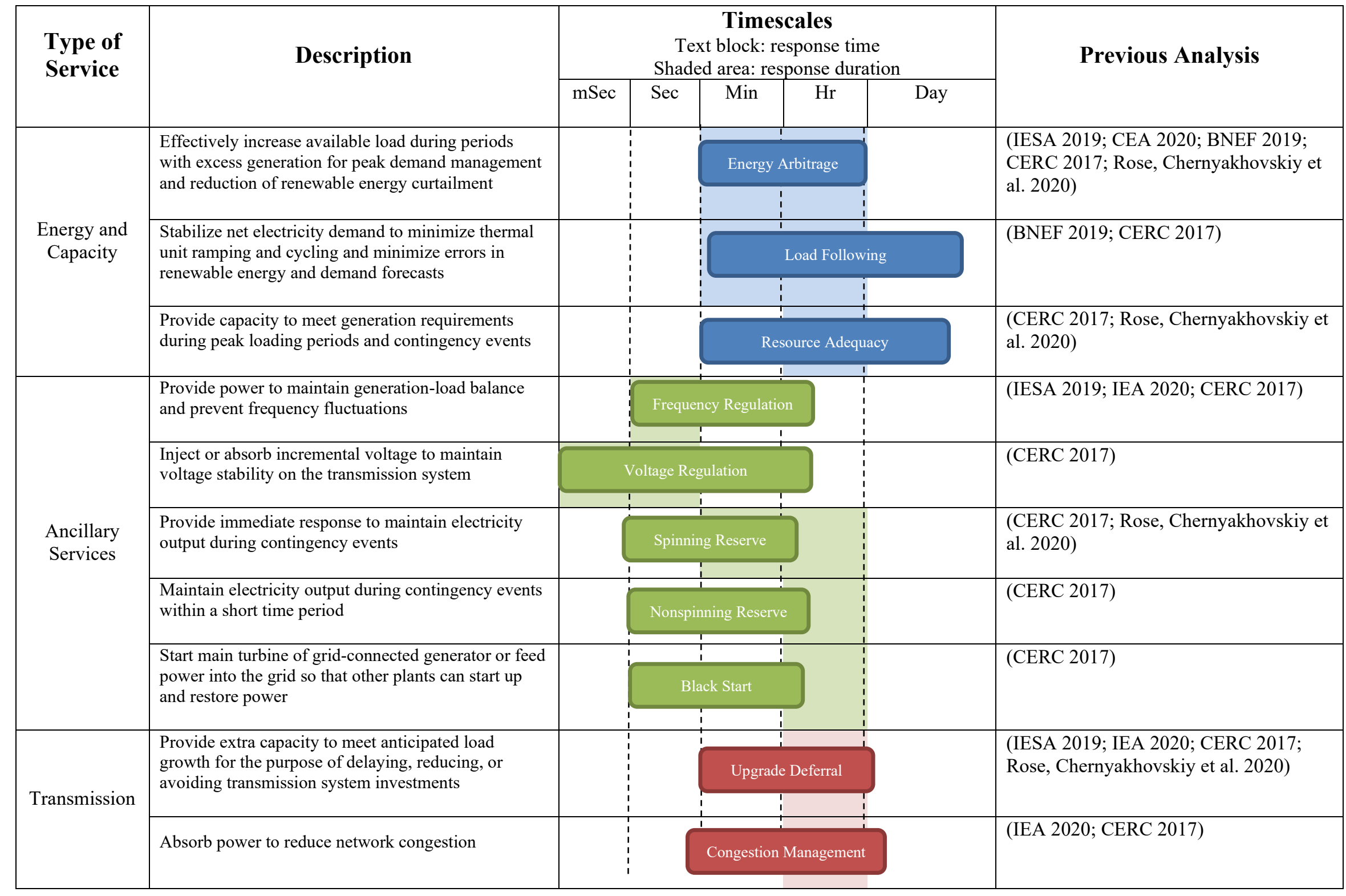


There are several technologies under consideration to provide these services. Pumped storage hydro (PSH) is the primary form of energy storage in the region. While there are no PSH projects in Nepal, several sites have been identified for project development, including the Kulekhani-Sisneri (100 MW), Begnas-Rupa (150 MW), Sunkoshi II (1,110 MW), and Sunkoshi III (536 MW) pumped storage hydro projects (New Business Age 2021; Renewable Energy World 2016; MOEWRI 2018a).

The Begnas-Rupa was envisioned as a pilot project to provide load following and peaking services for the Nepal grid but was recently stopped because the project was deemed too costly (MOEWRI 2018a; New Business Age 2021). The NEA is now surveying the Kulekhani-Sisneri project as a possible alternative. The two Sunkoshi projects are designed for export to Bangladesh. In 2016, Bangladesh and Nepal signed an agreement to develop the projects as part of the Bangladesh, Bhutan, India, Nepal initiative to facilitate regional trade and business development (Renewable Energy World 2016). However, there has been limited progress to advance these projects and there is no timeline for their completion at the time of this writing.

Although many suitable candidate sites for PSH may exist, the development of these sites may be limited by the large capital investments required as well as concerns around displacing agricultural lands, forests, and communities, in addition to disputes over water rights.

More recently, battery technologies are being piloted globally to serve a wide range of grid applications. Batteries can respond to signals to charge or discharge in less than a second, making them suitable for fast-response grid stability services such as frequency regulation. They can also be scaled to meet large demand needs by configuring multiple batteries in parallel with a discharge duration of minutes to hours, enabling them to provide longer-duration services such as resource adequacy, energy arbitrage, and load following. In Nepal, battery storage is primarily mentioned in the context of off-grid power applications paired with solar photovoltaic (PV) or ROR systems.

Lithium-ion batteries are the most widely used battery storage option today and control more than $90 \%$ of the global grid battery storage market (Mongird et al. 2019). Compared to other battery technologies, lithium-ion batteries have a high energy density, are lightweight, and cost less. These cost and performance advantages make lithium-ion the primary battery storage option being deployed globally.

In Nepal, applications for lithium-ion batteries are primarily focused on the transportation sector. With help from organizations such as the Electric Vehicle Association of Nepal, lithium-ion batteries are being piloted in the country's Safa Tempos, public transport vehicles conventionally powered by lead acid batteries (CEN and REPIC 2019). As of 2019, more than 25 Safa Tempos have switched to lithium-ion batteries.

While there are not cost estimates for deploying lithium-ion batteries in Nepal, estimates from India indicate lithium-ion batteries will become cost-competitive with open-cycle gas turbine plants to meet peak demand in India by 2025, and lithium-ion batteries paired with wind or solar projects are expected to become economic even sooner (BNEF 2019). If battery costs in Nepal are similar to those in neighboring India, lithium-ion batteries could be cost competitive with 
Nepal's diesel plants or imported power from India to meet demand during peak hours and during the dry season months.

Lead acid batteries are among the first battery technologies used for energy storage; however, compared to lithium-ion batteries, they have a low energy density and shorter cycle and calendar life. As a result, lead acid batteries are increasingly limited to backup power or remote grid applications. Recent efforts on advanced lead acid batteries seek to overcome the issue of poor life cycle and slow charging rates.

Lead acid batteries were primarily used as a backup power source for households and businesses when Nepal was experiencing supply shortages and load shedding was a frequency occurrence. However, as the supply situation improved beginning the 2016, battery sales for power system applications have declined (Nepal Energy Forum 2017). There are no utility-scale storage projects using lead acid batteries in Nepal today.

Flow batteries present an emerging alternative to lithium-ion. This technology stores energy directly in the electrolyte solution for longer cycle life and quick response times. Flow batteries are in early stages of commercialization compared to other battery technologies; however, their long life cycles, higher depth of discharge, and easy scalability offer advantages over other systems (Mongird et al. 2019). There are no existing or proposed flow battery projects in Nepal. 


\section{Text Box 1. The Energy Storage Market in the United States}

Energy storage has been growing rapidly in the United States, driven by falling technology costs and public policies. While PSH still accounts for $95 \%$ of front-of-the-meter (FTM) energy storage capacity in the United States, more than $1 \mathrm{GW}$ of nonhydro battery capacity has been added to date. The share of nonhydro FTM energy storage investments is expected to increase further, with an additional $81 \mathrm{GW}$ projected to be added by 2025 (Wood Mackenzie 2019). Cost declines for FTM systems are expected to continue in the coming years. System prices for long- and medium-duration FTM systems are expected to decline by $15 \%$ from 2019 to 2021.

The growing contribution of renewables in states across the United States has been a key driver for the storage industry. Thirty-seven states have either legally binding renewable portfolio standards or voluntary renewables goals (NCSL 2020). Seven states have also set targets or mandates explicitly for storage (Burwen 2020). Many utilities are installing storage through requests for proposals for capacity fulfillment or as an add-on to solar and wind projects. Other states encourage storage through pilot installations. On the federal level, attempts to pass storage incentives have so far stalled, although storage projects charged by renewables for $>75 \%$ of the time can take advantage of existing investment tax credits as well as a Modified Accelerated Cost Recovery System depreciation reduction (Elgqvist, Anderson, and Settle 2018).

As investments increase, regulators at the federal and state level are responding to remove barriers for energy storage and better capture the unique features of storage technologies. Federal Energy Regulatory Commission (FERC) Order 841 directs U.S. markets to create rules for energy storage to participate in wholesale, capacity, and ancillary service markets on a nondiscriminatory basis alongside other assets (FERC 2018). While FERC Order 841 seeks to remove barriers for energy storage, it gives markets discretion to design their own rules for compliance, allowing for multiple solutions.

Other regulations seek to improve existing compensation mechanisms to better capture the value energy storage and other technologies provide to the system. For instance, FERC Order 755 requires U.S. markets to adopt a two-part market-based compensation mechanism for frequency regulation services: a capacity payment that reflects the opportunity cost of not using the resource for some other service and a market-based performance payment that rewards faster-ramping resources (FERC 2011). In the PJM territory, this led to a tripling of fast-moving resources available for frequency regulation (Tweed 2013). Because these resources can respond to signals more quickly and accurately, PJM was able to lower its regulation requirements.

In Texas, the state legislature amended a rule to allow municipal utilities and electric cooperatives to own energy storage facilities without registering as a power generator. This change enables utilities to use storage facilities to defer or avoid the need for network investments (Mai 2019).

The United States is in a familiarization phase with energy storage. Policy programs have been instrumental in directing the scope and scale of storage deployment, while regulatory reforms have focused on establishing a level playing field for energy storage to provide grid services and be compensated for those services without being overly prescriptive. 


\section{Energy Storage Readiness Assessment}

The Energy Storage Readiness Assessment developed by NREL identifies 20 technical and nontechnical factors that enable energy storage investments and operation (Rose, Koebrich et al. 2020). These factors are grouped into three topics: System Characteristics, Policy, and Regulation.

Table 2. Components of the Energy Storage Readiness Assessment

\begin{tabular}{|c|c|c|}
\hline$\overline{\text { Topic }}$ & No. & Criteria \\
\hline \multirow{7}{*}{$\begin{array}{c}\text { System } \\
\text { Characteristics }\end{array}$} & 1 & Low or decreasing load factor in electricity demand \\
\hline & 2 & Inadequate or costly provision of ancillary services \\
\hline & 3 & Inadequate or costly supply options during peak demand periods \\
\hline & 4 & Increasing levels of transmission congestion \\
\hline & 5 & Proposed network upgrades with low anticipated utilization \\
\hline & 6 & Low flexibility in the generation mix \\
\hline & 7 & Increasing VRE curtailment \\
\hline \multirow{6}{*}{ Policy } & 8 & Storage included in energy policy and master plan \\
\hline & 9 & Targets for storage deployment \\
\hline & 10 & Energy strategy promotes operational flexibility \\
\hline & 11 & $\begin{array}{l}\text { Support organized knowledge sharing and delivery for scale-up and } \\
\text { replication }\end{array}$ \\
\hline & 12 & Domestic industrial policy supporting storage manufacturing \\
\hline & 13 & Targeted support to early adopters \\
\hline \multirow{7}{*}{ Regulation } & 14 & Utilities and private developers allowed to make storage investments \\
\hline & 15 & $\begin{array}{l}\text { Interconnection processes give storage the right to interconnect and } \\
\text { obtain transmission service }\end{array}$ \\
\hline & 16 & $\begin{array}{l}\text { Promotion of high-quality standardized energy storage technologies } \\
\text { through safety standards }\end{array}$ \\
\hline & 17 & Operating requirements for fast-responding assets \\
\hline & 18 & $\begin{array}{l}\text { Electricity services charges reflect value of and increase price } \\
\text { transparency for energy services }\end{array}$ \\
\hline & 19 & $\begin{array}{l}\text { Storage able to compete with other grid assets to provide multiple } \\
\text { services }\end{array}$ \\
\hline & 20 & Storage able to receive revenue for providing multiple services \\
\hline
\end{tabular}

The system characteristics capture the technical aspects that qualitatively describe the power system, such as changes in load shape, adequacy in capacity and ancillary services, and utilization of the transmission network. This section identifies operational and planning challenges that commonly afflict rapidly changing grids where energy storage could contribute to the solution. These characteristics can help identify whether there is a technical or economic need for utility-scale energy storage.

The policy criteria cover the set of guidelines that direct the scope and scale of storage deployment. These topics span early-stage exploration into the feasibility of integrating energy storage through establishing deployment targets and support programs to grow the industry. The 
goal of these activities is to accelerate the identification and implementation of appropriate energy storage solutions should the GoN decide to do so.

The regulatory topics capture the set of rules necessary to define how energy storage technologies should be treated. These include rules around ownership and planning, as well as operational practices, tariffs, and safety standards. The regulations could enable energy storage to compete on a nondiscriminatory basis with other grid assets to provide grid services and be compensated for those services.

To complete the Energy Storage Readiness Assessment, each criterion is assigned a color-based grade based on the evaluation scheme in Figure 1.

\section{Status Grade Description}

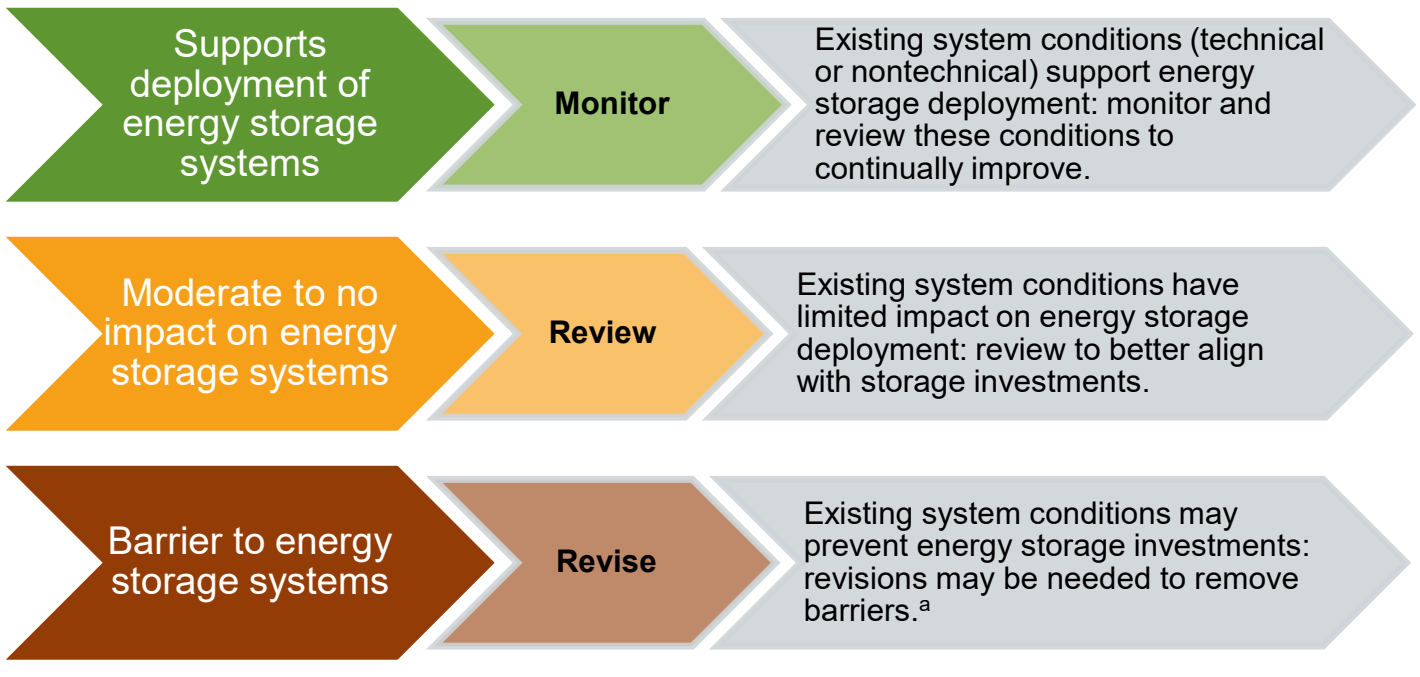

Figure 1. Evaluation scheme for Energy Storage Readiness Assessments

a Revisions may not be recommended for system characteristics where conditions that are good for the overall system (i.e., high levels of system flexibility and reliability) may not support energy storage investments.

The "Monitor" grade indicates existing system conditions support energy storage deployment. These conditions should be monitored to identify areas for continued improvement. In cases where system conditions have limited impact - positive or negative - on energy storage deployment, a grade of "Review" can be given. This indicates the need to review and, if desirable, update policy or regulatory frameworks to better align with energy storage deployment. Finally, criteria that present a barrier to energy storage are given a grade of "Revise," indicating action may be required to remove existing conditions that may be preventing investments in energy storage.

This assessment is designed to allow policy makers and regulators to quickly gauge how well existing policy and regulatory frameworks support energy storage. As such, it is not designed to recommend specific policy or regulatory solutions but rather to identify priority areas for focus. It is also not designed to inform whether energy storage is the best solution among other possible technical and nontechnical interventions to meet system needs. Furthermore, a given system may need to be reassessed periodically as system conditions change. 


\section{Application of the Readiness Assessment: Nepal}

As Nepal continues to update its power sector policy and regulatory frameworks, policy makers and regulators have an opportunity to put in place a suite of policies, programs, and regulations to enable energy storage investments and maximize their value to the system. In this section, we apply the Energy Storage Readiness Assessment to Nepal's power system to inform this dialogue and assist policy makers and regulators in identifying priority areas for focus moving forward.

\subsection{Brief Overview of Nepal's Power Sector}

Nepal's electricity sector is governed by the Ministry of Energy, Water Resources, and Irrigation. In May 2019, the Electricity Regulatory Commission (ERC) was established to serve as the independent regulatory body for electricity. With the creation of the ERC, the government has effectively removed itself from direct electricity regulation, particularly with respect to tariff setting and consumer protection. In June 2020, the ERC issued its first independent and costreflective tariff for the NEA and has been assuming increased responsibility, including the development of a new grid code.

The NEA was established under the Nepal Electricity Authority Act, 1984, as the state-owned utility responsible for generation, transmission, and distribution of electricity in the country (Government of Nepal 1984). In 2015, the GoN established the Rastriya Prasaran Grid Company Limited (RPGCL) to plan, construct, and operate the transmission grid. In the generation sector, both the government and the private sector are involved in developing projects. Of the country's 1,328 MW of grid-connected installed capacity in 2020,696 MW are owned by independent power producers (IPPs) (NEA 2020b). IPP-owned capacity comprises exclusively ROR or peaking ROR plants. The NEA owns the remaining $48 \%$ of the country's installed capacity, including $582 \mathrm{MW}$ of hydropower.

The NEA is the counterparty to all power purchase agreements and the owner and operator of Nepal's transmission network. Therefore, improving the technical and commercial viability of the NEA has been a priority focus of recent reform efforts. In 2017, the government approved a tariff increase for the NEA, including commitments to reduce losses and load shedding, more effective and decisive management, and a government-endorsed financial restructuring plan for the NEA (ESMAP 2019).

The creation of the ERC resulted in a structured and continuous approach to cost-reflective tariff setting. In 2020, the NEA released its first ever Corporate Development Plan (CDP) (NEA 2020a). The plan sets out several operational goals aimed at expanding and improving electricity service and reduce Nepal's reliance on imported power. Other structural reforms have targeted improvements to the distribution sector. The complex task of devolution of responsibility for electricity distribution from the NEA to provincial authorities is underway.

Nepal's hydro-based electricity supply experiences severe seasonal imbalances. ROR and PROR plants, which comprise $86 \%$ of the country's installed capacity, can generate only about a third of their total installed capacity during the dry season (NEA 2020a). The country relies on imports of power from India to meet supply deficits during peak demand periods and during the dry season months. The planned hydropower expansion in Nepal aims to reduce the country's reliance on imports and increase revenues from exports of surplus hydropower generation, but 
imports from neighboring countries may continue to be essential to meet seasonal and diurnal imbalances. Recognizing the increasingly important role that cross-border electricity trade plays in Nepal's power sector, the Nepal Power Trading Company Limited was established in 2017 to serve as a single agent responsible for cross-border electricity trading activities (Adhikari 2018). Subsequent regulations establish cross-border electricity trading as a separate licensed activity alongside generation, transmission, and distribution of electricity (Government of Nepal 2017).

\subsection{Assessment Summary}

Table 3 summarizes the results of the energy storage readiness assessment for Nepal. Subsequent sections present detailed analysis of how the results are obtained for each criterion. In general, the technical characteristics of the Nepali power system are favorable for energy storage, while the policy and regulatory frameworks are largely unsupportive; however, this is mostly due to an absence of storage considerations in current frameworks rather than poorly designed energy storage policies or rules. 


\section{Table 3. Results of Readiness Assessment for Nepal}

\begin{tabular}{|c|c|c|c|c|}
\hline Topic & No. & Criteria & Assessment & Notes \\
\hline \multirow{7}{*}{$\begin{array}{l}\text { System } \\
\text { Characteristics }\end{array}$} & 1 & Low or decreasing load factor in electricity demand & & Load factors are increasing while peak demand is decreasing. \\
\hline & 2 & Inadequate or costly provision of ancillary services & & $\begin{array}{l}\text { System modeling indicates energy storage could be a cost- } \\
\text { effective option to meet new ancillary service requirements }\end{array}$ \\
\hline & 3 & $\begin{array}{l}\text { Inadequate or costly supply options during peak } \\
\text { demand periods }\end{array}$ & & $\begin{array}{l}\text { Storage is increasingly cost-effective with IPP hydropower and } \\
\text { Indian imports to meet peak demand }\end{array}$ \\
\hline & 4 & Increasing levels of transmission congestion & & Specific corridors experiencing overloading \\
\hline & 5 & $\begin{array}{l}\text { Proposed network upgrades with low anticipated } \\
\text { utilization }\end{array}$ & & Proposed upgrades anticipated to have high utilization \\
\hline & 6 & Low flexibility in the generation mix & & $\begin{array}{l}\text { Maximum flexibility requirements are increasing, exceeding the } \\
\text { capabilities of the generation fleet, but these instances are } \\
\text { occurring less frequently }\end{array}$ \\
\hline & 7 & $\begin{array}{l}\text { Increasing curtailment of variable renewable energy } \\
\text { (VRE) }\end{array}$ & & $\begin{array}{l}\text { No curtailment of VRE to date; storage could reduce curtailment } \\
\text { of ROR hydropower }\end{array}$ \\
\hline \multirow{6}{*}{ Policy } & 8 & Inclusion of storage in energy policy and master plan & & $\begin{array}{l}\text { No clear policy vision for energy storage; existing plans focused } \\
\text { on pumped storage hydropower (PSH) }\end{array}$ \\
\hline & 9 & Targets for storage deployment & & $\begin{array}{l}\text { No specific targets for utility-scale storage; PSH included among } \\
\text { other technologies in generation mix target }\end{array}$ \\
\hline & 10 & Energy strategy promotes operational flexibility & & $\begin{array}{l}\text { Recent initiatives focus on flexibility, but opportunities for } \\
\text { storage to meet flexibility needs are limited }\end{array}$ \\
\hline & 11 & $\begin{array}{l}\text { Support organized knowledge sharing and delivery } \\
\text { for scale-up and replication }\end{array}$ & & No initiatives or organizations focused on promoting storage \\
\hline & 12 & $\begin{array}{l}\text { Domestic industrial policy supports storage } \\
\text { manufacturing }\end{array}$ & & $\begin{array}{l}\text { Industrial policy includes energy sector among prioritized sectors } \\
\text { but no specific manufacturing programs }\end{array}$ \\
\hline & 13 & Targeted support to early adopters & & Support focused on pilot PSH projects \\
\hline \multirow{7}{*}{ Regulation } & 14 & $\begin{array}{l}\text { Utilities and private developers allowed to make } \\
\text { storage investments }\end{array}$ & & For nonhydro storage, development limited to hybrid projects \\
\hline & 15 & $\begin{array}{l}\text { Interconnection processes give storage the right to } \\
\text { interconnect and obtains transmission service }\end{array}$ & & PSH or hybrid storage projects can connect as generation assets \\
\hline & 16 & $\begin{array}{l}\text { Promotion of high-quality standardized energy } \\
\text { storage technologies through safety standards }\end{array}$ & & No safety standards in place or underway \\
\hline & 17 & Operating requirements for fast-responding assets & & Only PSH can provide most services \\
\hline & 18 & $\begin{array}{l}\text { Electricity services charges reflect value of and } \\
\text { increase price transparency for energy services }\end{array}$ & & $\begin{array}{l}\text { Contract rates and consumer tariffs include time of day and } \\
\text { seasonal components }\end{array}$ \\
\hline & 19 & $\begin{array}{l}\text { Storage able to compete with other grid assets to } \\
\text { provide multiple services }\end{array}$ & & Opportunities limited to PSH or hybrid projects \\
\hline & 20 & $\begin{array}{l}\text { Storage able to receive revenue for providing } \\
\text { multiple services }\end{array}$ & & $\begin{array}{l}\text { Compensation for services beyond power provides is not } \\
\text { available }\end{array}$ \\
\hline
\end{tabular}




\subsection{System Characteristics}

The technical characteristics of Nepal's power system are somewhat favorable for energy storage. There are opportunities for energy storage to provide ancillary services and demand during peak periods and dry season months.

\section{Low or Decreasing Load Factor in Electricity Demand}

Review

Load factor is an expression of the utilization of the system. Low load factors indicate volatility in demand and sometimes require that capital-intensive generation or transmission resources be built to serve load only for a short time. While Nepal is pursuing programs to increase electricity access and electricity consumption, parallel efforts are underway to promote energy efficiency and reduce losses (MOEWRI 2018b). The result is lower overall peak demand and higher load factors in recent years. Figure 2 shows the variation Nepal's monthly load factor from 2016 through $2019^{5}$ (NEA 2019b; 2020b).

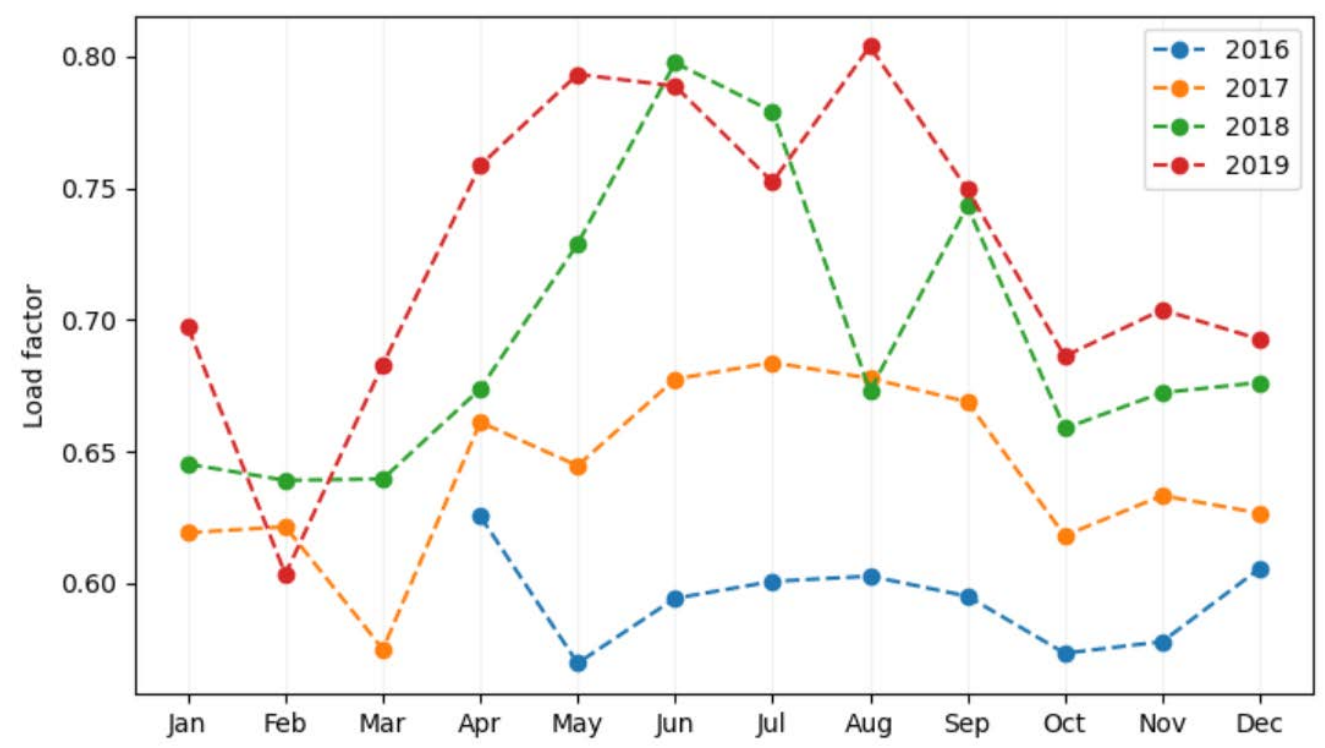

Figure 2. Nepal's monthly load factor, 2016-2019

Two trends emerge from examining Nepal's monthly load factors over time. First, annual load factors are increasing from $41.8 \%$ in 2016 to $64.2 \%$ in 2019 on average. This indicates the hourly load profile is becoming "flatter" with less variation between low and high demand periods. Second, there is an increasingly seasonal pattern of low and high load factors, with high load factors (i.e., flatter demand profiles) during the summer and lower load factors (i.e., more variable demand profiles) during the winter. This indicates that, while overall load factors are increasing, there could be seasonal opportunities for energy storage technologies to provide load following or energy arbitrage services.

${ }^{5} 2020$ data is not included to exclude the effect COVID pandemic. 
To understand what these opportunities may be, we analyzed hourly load profiles for the maximum demand day. Figure 3 compares the hourly load profile for the maximum demand day over the Fiscal Years (FY) 2016/17 through FY 2019/20 (NEA 2017b; 2018; 2019b; 2020b).

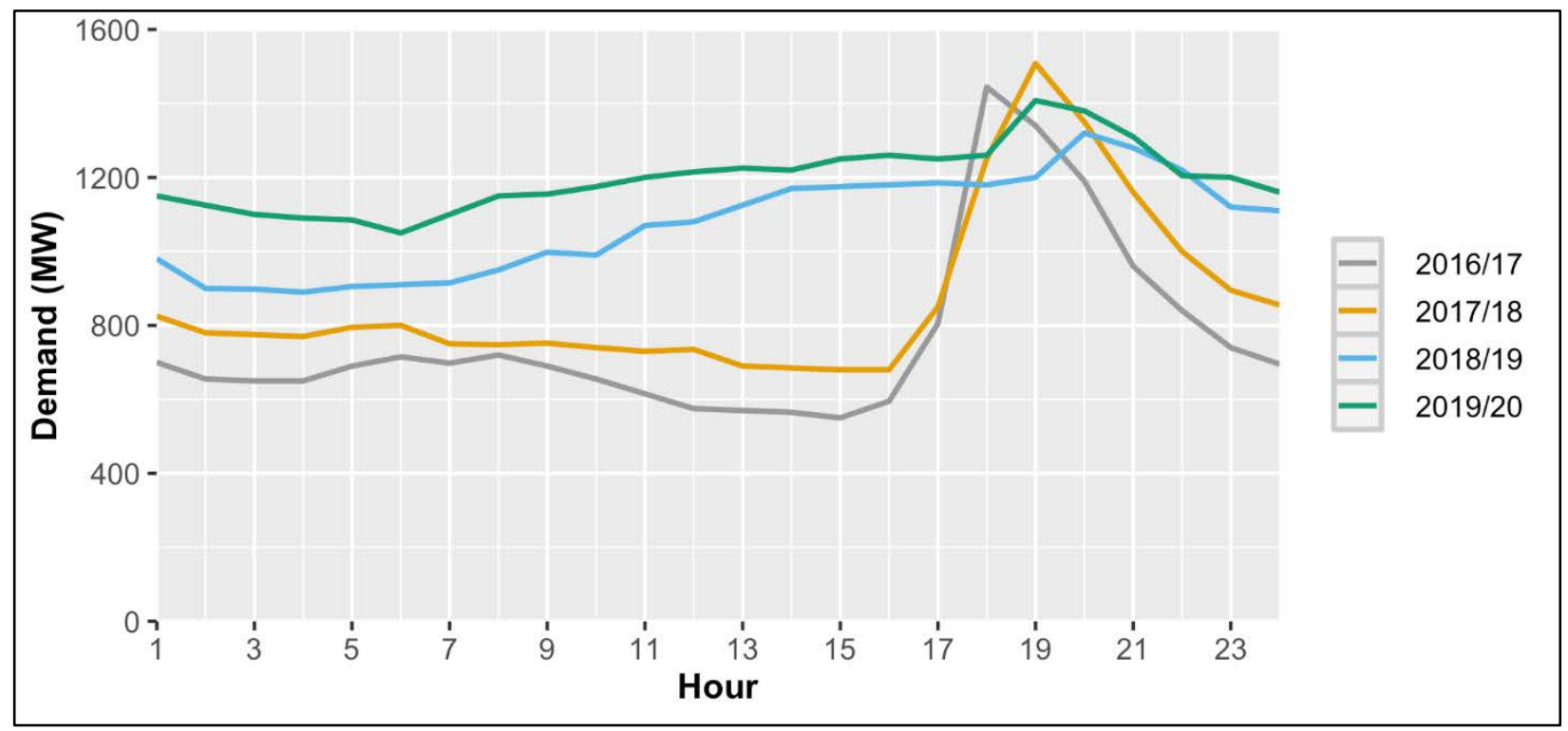

Figure 3. Change in hourly load profile on maximum demand day, FY 2016/17-FY 2019/20

Over the 4-year period, the maximum daily load profile in Nepal has become flatter. While peak load still occurs in the evening, the peak demand as well as the difference between peak and offpeak demand has decreased. In FY 2016/17, the peak demand reached 1,444 MW, and the ratio of peak to off-peak demand was 2.6. By FY 2019/20, peak demand was 1,408 MW, and the ratio of peak to off-peak demand was 1.3 .

Energy storage technologies can be used to reduce daily variability in electricity demand by charging during off-peak hours and discharging during peak demand periods. In Nepal, the need and opportunity for energy storage to provide this service is decreasing. Load factors have been increasing and peak demand decreasing on an annual basis. While these conditions may change as electricity demand continues to grow, the near-term outlook for energy storage to provide load following and peak demand management is not favorable.

\section{Inadequate or Costly Provision of Ancillary Services}

Monitor

Nepal's ancillary services sector is still in the development phase. The grid code establishes voltage, frequency, and power factor requirements for all licensees, but these entities are not required to hold reserves for frequency regulation, contingency reserves, or black start (Government of Nepal 1992). The load dispatch center must rely on unscheduled surplus NEAowned resources to provide these services. Further, the grid code does not set out the quantum of reserves that are required. Therefore, it is difficult to judge whether the supply of ancillary services in the country is adequate.

In its Draft Grid Code, the ERC proposed a range of new ancillary service requirements, including primary and secondary frequency regulation, spinning reserve, backup reserve, and 
black start (ERC 2020b). Under the proposed rules, all generators synchronized to the grid are required to provide spinning reserves, and all conventional generators (i.e., not variable renewable energy generators) are required to provide primary and secondary frequency regulation. Notably, under current regulations, PSH is the only storage technology eligible to provide ancillary services.

To understand the role energy storage could play to provide ancillary services in Nepal ${ }^{6}$, NREL developed an hourly production cost model of the Nepali power system in the year 2030 (Chernyakhovskiy et al. 2021). The modeled Nepali system includes official projections for growth in electricity demand as well as generation and transmission capacity (MOEWRI 2018a; RPGCL 2018; Water and Energy Commission Secretariat 2017).

We analyzed multiple scenarios of energy storage build-out in Nepal by adding an incremental quantum of 4-hour energy storage and optimizing the mix of resources required to meet energy and ancillary service needs at least cost. We find that adding $500 \mathrm{MW}$ of energy storage can provide $69 \%$ of total reserve requirements. Adding $100 \mathrm{MW}$ of energy storage can provide $44 \%$ of total reserve requirements. The remaining reserve requirements are fulfilled by reservoir storage hydro plants.

This indicates that if energy storage-beyond $\mathrm{PSH}-$ is allowed to provide ancillary services in Nepal, it could increase reliability by contributing to operating reserves while providing other valuable grid services.

\section{Inadequate or Costly Supply Options During Peak Demand Periods}

In May 2018, the NEA ended a decade of load shedding. While the country is now able to meet its electricity demand needs throughout the year, the cost of supply during peak demand periods and dry season months increases sharply. Electricity supply during peak demand periods is provided by Nepal's PROR and reservoir storage hydropower plants and imports from India.

Imports from India are the most expensive supply option during non-dry-season months, purchased at an average rate of NPR ${ }^{7} 6.7$ per kWh (2020), down from NPR 7.0 per kWh in 2019 (NEA 2020b). From July 2019 through July 2020, imports from India accounted for 22\% of Nepal's electricity supply. The vast majority, $90 \%$, of these imports occur during the dry season (ERC 2020a). During this season, power purchased from domestic IPP hydropower projects is also more expensive, with tariffs ranging from NPR 8.4 to NPR 12.4 per $\mathrm{kWh}$, depending on the plant type and time of day.

Energy storage presents an increasingly cost-competitive alternative to meet existing and future demand needs during peak periods and dry season months. Energy storage could also bolster the ability of renewable generators to serve as peaking resources through hybrid projects. In neighboring India, Bloomberg New Energy Finance estimates a new PV or wind power project

\footnotetext{
${ }^{6}$ Though there are no existing regulations related to operating reserves in the country, we assumed $5 \%$ of load as the reserve requirement for this analysis.

${ }^{7}$ A Nepalese rupee (NPR) is equivalent to 0.84 U.S. cents and 0.63 Indian rupees.
} 
with 1-hour battery storage is already competitive with gas power plants (BNEF 2019). Falling battery prices could make longer-duration hybrid projects competitive by 2030 . In fact, some of these prices are already being achieved. The first centralized auction for renewable energy paired with energy storage in India to provide "round-the-clock" renewable power in May 2020 achieved a tariff of 2.9 Indian rupees (NPR 4.6) per $\mathrm{kWh}$, almost half the tariff rate for IPP hydropower in the dry season (Gupta 2019).

The potential cost savings has generated interest in renewable plus storage hybrids in Nepal as well. In 2018, the Doma Himalayan Climate Fund proposed a 150-MW solar PV and 20-MW battery storage project aimed at managing morning and evening peak demand (Dixit 2018). The project's promotors noted that it can take a decade to commission one of Nepal's big reservoir storage hydropower projects, whereas a new storage or solar-storage hybrid project can be completed within 2 years. And the energy generated could be purchased at a lower price than what Nepal is currently paying for imports from India.

Energy storage could also be paired with new or existing ROR or PROR hydropower plants to increase the peaking capacity from these facilities. This could be an economic alternative to investments in new storage or PROR capacity as well as imports from India.

\section{Increasing Levels of Transmission Congestion}

\section{Review}

The Terai region of Nepal is experiencing transmission line overloading, causing poor voltage profile and unreliable power supply (NEA 2017b; 2019a). Some of the regions experiencing congestion are Saptari, Udayapur, Nepalgunj, Banke, Jhapa, Dharan, and Biratnagar (Figure 4). Most of the areas experiencing overloading are industrial areas, which tend to have consistent electricity demand throughout the day. Therefore, the overloading is likely to be frequent throughout the day and year.

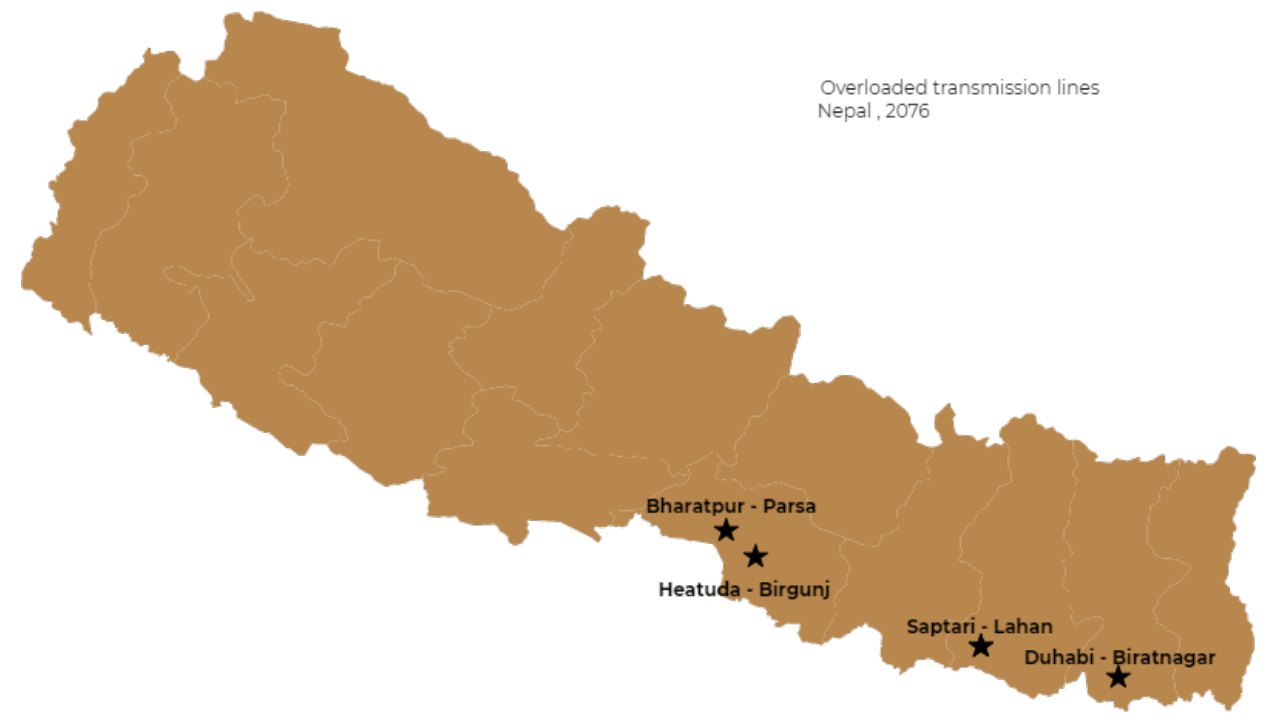

Figure 4. Overloaded transmission lines in Nepal, 2019 
The GoN has several projects underway to upgrade transmission lines and substations in these areas. Upgrading and installing new transmission lines may take between 5 and 10 years to finish (NEA 2019a). Energy storage can improve network operations by absorbing or injecting power to reduce congestion and improve overall transmission utilization as a near-term solution.

As the patterns of network flows change in response to changes in demand or investments in generation and transmission assets, some energy storage technologies can be relocated when no longer needed, increasing their overall value to the grid (Bowen, Chernyakhovskiy, and Denholm 2019). For example, New York City utility Con Edison (ConEd) is piloting a mobile tractor-trailer-based 1-MW/4-MWh battery storage system that readily relocates to where it is most useful (Maloney 2017). However, if existing overloading near industrial areas is nearconstant due to the demand patterns of industrial consumers, utility-scale energy storage is unlikely to replace or defer the need for network upgrades to relieve congestion.

\section{Proposed Network Upgrades with Low Anticipated Utilization}

Review

Nepal has undertaken significant expansion of the country's transmission network. Over the past 7 years, total transmission line length increased by 50\% (NEA 2017b). In addition to intranational network expansion, the recently commissioned Dhalkebar-Muzzaffurpur 400-kV transmission line increased cross-border electricity import/export capacity with India to 1,000 MW (Himalayan News Service, 2020).

Most of the transmission and substation upgrades are implemented to ensure the system meets N1 contingency requirements, decrease transmission lines losses, and evacuate power from large hydro plants. These issues currently exist or are anticipated to arise in the near future. As a result, the network upgrades are anticipated to have a high rate of utilization upon commissioning. Therefore, there are no significant opportunities for energy storage to delay, reduce, or defer investments in transmission infrastructure in the near or intermediate future.

\section{Low Flexibility in the Generation Mix}

Review

Growth in electricity demand and programs to reduce peak demand changed the flexibility requirements for Nepal's power system. We used hourly load data for the 2016-2017 operating year and data on annual growth in peak demand and total energy consumption to examine changes in Nepal's load shape over the 2016-2020 period (Open Data Nepal n.d.; NEA 2019b; $2020 \mathrm{~b}$ ). Using this estimate, the maximum hourly ramping requirement has fallen slightly from 1,020 MW/h in 2016-2017 to $995 \mathrm{MW} / \mathrm{h}$ in 2019-2020 (Figure 5). The median hourly ramping requirement for the generation fleet has also fallen slightly from $306 \mathrm{MW} / \mathrm{h}$ to $297 \mathrm{MW} / \mathrm{h}$. 


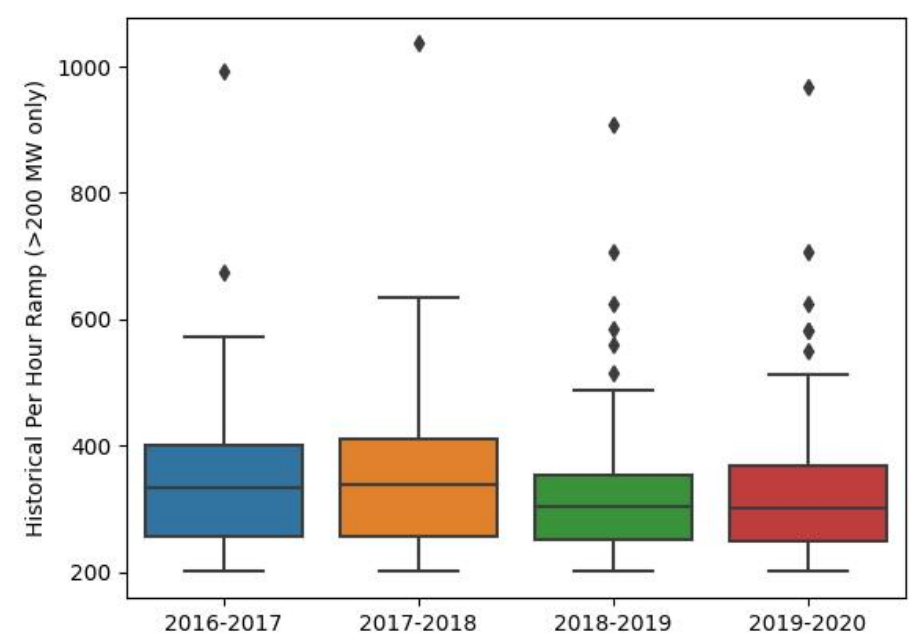

Figure 5. Box plot of historical per hour ramp-up, Nepal 2016-2020

While the maximum hourly ramping requirement has decreased, the number of hours in which the generation fleet must meet this need has increased. In 2016-2017, the hourly ramping requirement exceeded $200 \mathrm{MW}$ in 7\% of hours. By 2019, the system experienced hourly ramps above $200 \mathrm{MW}$ in $9 \%$ of hours.

This need for more frequent ramping of generation assets to balance load has implications for the investment and operational needs of the generation fleet. At present, the NEA has just over 450 MW of installed capacity capable of meeting its ramping requirements and another $636 \mathrm{MW}$ under construction. This capacity is largely made of PROR plants with the rest comprised of reservoir storage (60 MW) and diesel or multifuel plants (53 MW) (NEA 2020b).

In the dry season, PROR plants can generate about a third of their total installed capacity (NEA 2020a). Therefore, despite the increase in flexible generation resources and decrease in average ramping requirements, Nepal may be unable to meet its ramping needs for a small number of hours in the year. Given the small number of hours in which additional flexibility is required, investments in new generation resources to meet flexibility needs may be uneconomic. Imports from India could serve as an alternative source of flexibility.

The newly completed Dhalkebar-Muzzafarpur 400-kV Nepal-India transmission link allows up to 1,000 MW of electricity to be transmitted between the two countries (Himalayan News Service 2020). While imports tend to be more expensive than domestic generation, this may be an economic alternative to new generation investments with low utilization.

Energy storage presents another alternative to increase system flexibility. A stand-alone storage facility, or storage paired with an ROR plant, can act as a flexible resource to meet ramping requirements and provide other grid services throughout the year. The trade-off between energy storage and other options to meet system flexibility needs will depend on many factors, including the periods in which additional flexibility is needed and costs of various options as well as considerations around security of supply and reliability. 


\section{Increasing Curtailment of Variable Renewable Energy}

Nepal's variable renewable energy capacity is limited to $1.35 \mathrm{MW}$ from three solar power plants (NEA 2020b). Therefore, curtailment of variable renewable energy is not a major issue. However, the country does experience curtailment of renewable hydropower generation ${ }^{8}$ due to seasonal surpluses. Data on the amount of hydropower that is curtailed each year, particularly during the wet season, is not publicly available.

To quantify the potential for hydropower curtailment and understand the role storage could play in reducing curtailment, NREL developed an hourly production cost model of the interconnected Bangladesh, Bhutan, India, Nepal system for the year 2030 (Chernyakhovskiy et al. 2021). Using official projections for growth in electricity demand as well as generation and transmission capacity, we analyzed multiple scenarios of energy storage buildout in Nepal by adding an incremental quantum of 4-hour energy storage.

Using our hourly production cost model, we observe that, with no energy storage, $0.6 \%$ of Nepal's hydropower generation is curtailed due to insufficient flexibility in 2030. Adding 4-hour energy storage in Nepal helps shift hydro generation to periods when it is needed, reducing hydro curtailment and increasing exports to India. Table 4 shows that adding up to $500 \mathrm{MW}$ of 4-hour energy storage reduces curtailment substantially and increases the opportunities for exporting formerly curtailed power to India, thus increasing the economic viability of hydropower investments in Nepal. We also tested scenarios with 1,000 MW, 2,000 MW, and 5,000 MW of storage capacity but do not see additional advantages in terms of reduced curtailment or increased exports.

Table 4. Change in Annual Nepal Exports to India with Incremental Energy Storage Additions

\begin{tabular}{|c|c|c|}
\hline $\begin{array}{c}\text { 4-hr energy storage } \\
\text { capacity }\end{array}$ & $\begin{array}{c}\text { Change in exports } \\
\text { to India (GWh) }\end{array}$ & $\begin{array}{c}\text { Hydro ROR } \\
\text { curtailment }\end{array}$ \\
\hline $0 \mathrm{MW}$ & - & $0.6 \%$ \\
\hline $100 \mathrm{MW}$ & 293 & $0.48 \%$ \\
\hline $300 \mathrm{MW}$ & 432 & $0.36 \%$ \\
\hline $500 \mathrm{MW}$ & 728 & $0.13 \%$ \\
\hline
\end{tabular}

Energy storage in Nepal could help maximize the use of the country's domestic hydropower resources, lowering curtailment and increasing exports to neighboring countries. In the near term, the technical and economic justification for energy storage is limited, as the contribution of variable renewable energy is low and hydropower curtailment is estimated to remain below $1 \%$.

\footnotetext{
${ }^{8}$ Run-of-river hydropower has very low or zero marginal costs to operate. Therefore, curtailing power, which is done by allowing water to flow past the dams, is wasting very low-cost energy that cannot be recovered.
} 


\subsection{Policy}

Nepal's energy policy framework does not articulate a clear vision for energy storage in the country. Existing public support for specific projects can inform the development of a clear policy framework for energy storage that addresses the many services that storage can provide as well as the full range of storage technologies available.

\section{Inclusion of Energy Storage in Energy Policy and Master Plan}

Revise

In the past, energy storage technologies have been largely excluded from Nepal's energy sector policy and planning documents. However, this is starting to change. The two primary policy documents that outline the government's vision for the energy sector are the Electricity Act 1992 and the 2018 White Paper on Energy, Water Resources, and Irrigation Sector's Current Status and Roadmap for Future (hereafter referred to as White Paper). Under the Electricity Act, energy storage would have to qualify as a generation, transmission, or distribution asset to obtain a license for operation (Government of Nepal 1992). The policy is silent as to whether energy storage, particularly nonhydro technologies, could qualify under one of these categories.

The more recent 2018 White Paper sets out a series of short-, medium-, and long-term policy objectives for the energy sector through 2028 to meet national priorities, including increased access to electricity and electricity consumption as well as improved national energy security (MOEWRI 2018a). These objectives provide the policy framework for planned activities outlined in the NEA's CDP (NEA 2020a). The plan includes a goal to improve energy security through the prioritized development of PROR plants, reservoir and PSH plants, and battery stations. While most of the focus is on accelerating the development of PROR and reservoir storage hydropower projects, the White Paper directs the NEA to continue with the development of the proposed Begnas-Rupa Pump Storage Project (150 MW) as a pilot project. This projectenvisioned as the first such project in the country - was dismissed by the NEA as too costly, and in March 2021 the Department of Electricity Development granted the NEA permission to begin surveying the Kulekhani-Sisneri pump storage project as an alternative (New Business Age 2021).

Battery storage is only mentioned in the context of off-grid systems paired with ROR or solar plants in the White Paper, but there are indications that nonhydro storage technologies could play a role in Nepal's future generation mix. In its CDP, the NEA notes that utility-scale storage technologies "would be an ideal fit for Nepal's hydro electricity generation profile" because storage could help match hydropower supplies to patterns of electricity demand. The NEA is starting to assess the financial viability of such technologies and work will be needed to define the policies and tariffs for utility-scale energy storage projects.

Overall, Nepal's energy policy does not articulate a clear vision for energy storage in the country. The proposed PSH pilot project is a useful step to explore the feasibility of integrating such a project onto the grid, and the NEA's planned assessment of the financial viability of battery storage technologies will help broaden the discussion beyond PHS. Both activities can inform the development of a clear policy framework for energy storage that addresses the many services storage can provide as well as the full range of storage technologies available. Having 
this framework in place can accelerate the identification and implementation of systemappropriate storage solutions.

\section{Targets for Storage Deployment}

\section{Review}

The Government of Nepal has outlined several targets aimed at catalyzing investments and expanding the energy sector. While there is no specific target for energy storage, $\mathrm{PSH}$ is included, among other technology options, to meet policy goals. The government's White Paper includes a goal to achieve $30-35 \%$ of generation from reservoir and PHS hydropower plants by 2030. Table 5 compares the 2030 target generation mix established in the White Paper with the current generation mix.

Table 5. Change in Generation Mix To Meet 2030 Policy Targets

\begin{tabular}{lcc}
\multicolumn{3}{c}{ Source: Adapted from NEA 2020a } \\
\hline Technology & $\begin{array}{c}2018 / 19 \\
(\%)\end{array}$ & $\begin{array}{c}2030 \text { Target } \\
(\%)\end{array}$ \\
\hline Reservoir and PSH & 9 & $30-35$ \\
PROR & 28 & $25-30$ \\
ROR & 58 & $30-35$ \\
Nonhydro Renewable & NA & $5-10$ \\
\hline
\end{tabular}

Notably, the design of the target itself may exclude other utility-scale storage technologies. Most energy storage technologies, such as batteries, are closed-loop systems. They do not have their own generation source, such as a free-flowing water source, and must charge from the grid to discharge back to the grid. Therefore, these technologies cannot contribute to a generation mix target because they do not generate electricity independently.

For policy makers in Nepal keen to catalyze investments in energy storage, there are other policy targets that could be pursued in parallel to the country's goals for its generation mix. For example, Indian Minister of Power R. K. Singh has proposed introducing a renewable purchase obligation for round-the-clock power as a mechanism to promote energy storage (ET Energy World 2020). Under the proposed scheme, increased demand for energy storage would increase investments in storage manufacturing facilities, driving down storage costs and accelerating the transition to renewable energy. Targets can be set in terms of either megawatts of installed capacity or megawatt-hours (MWh) of utilization and may increase over time (e.g., storage target is $1 \%$ of generating capacity by 2030 and $3 \%$ by 2035 ).

Efforts to assess the economic feasibility of energy storage, such as the NEA's planned assessment for battery systems, can inform future policy targets. The results of NREL's power system modeling to better understand the techno-economic potential for energy storage in the 
region can also help inform where and when utility-scale energy storage is cost-effective and the drivers for energy storage investments. ${ }^{9}$

\section{Energy Strategy Promotes Operational Flexibility}

Review

Increasing the flexibility of Nepal's power system is central to the country's energy strategy. Efforts to increase operational flexibility include promoting a more flexible generation mix, making changes to the grid code, and increasing trade with neighboring countries. National goals to promote a more flexible generation mix are outlined in the White Paper. It emphasizes the development of reservoir or PSH projects, including an aspirational goal that "one storage type [hydro] project will be in each province as far as possible." The strategy also proposes to give priority approval to PROR plants over ROR plants in cases where separate applications are submitted for development of the same area.

Updates to the electricity grid code also aim to increase the flexibility of generating units and expand ancillary service requirements to enable the system to better respond to unexpected deviations. These include requirements for large generating units to be fitted with automatic generation control and able to increase their output at least 5\% over their maximum continuous rating for up to five minutes (ERC 2020b).

To ensure the system has adequate reserves, the new grid code requires all generators synchronized to the grid to provide spinning reserves and all conventional generators to provide primary and secondary frequency regulation. Under current regulations, PSH is the only storage technology eligible to provide these services. Adding other energy storage technologies could be beneficial for enhancing flexibility, as several energy storage technologies have comparable or faster response times.

Finally, Nepal is looking to expand cross-border trade with neighboring countries, particularly India, to manage seasonal and diurnal imbalances. Electricity market integration across the region is increasing due to investments in new cross-border transmission interconnections and market reforms to enable greater cross-border power trading.

India and Nepal can exchange up to 1,000 MW of electricity via the newly completed Dhalkebar-Muzzafarpur 400-kV transmission link (Himalayan News Service 2020). A second interconnection between New Butwal (Nepal) and Gorakhpur (India) is under development, and three other high-voltage interconnections are being studied (NEA 2020a). Further, India has opened its power exchanges to neighboring countries allowing Nepal to trade power through the day-ahead and term-ahead markets. The NEA plans to participate in these markets, using trade with India to manage system imbalances and maximize the efficient use of its generation resources.

Promoting greater operational flexibility through policy goals and regulations for fast-responding assets can improve system reliability. And expanding the range of storage technologies eligible

\footnotetext{
${ }^{9}$ For more information, see https://www.nrel.gov/international/energy-storage-south-asia.html.
} 
to meet flexibility needs beyond PSH can increase the total amount of fast-responding assets available for balancing.

\section{Support Organized Knowledge Sharing and Delivery for Scale-Up and Replication}

Review

There are currently no initiatives or organizations focused on promoting energy storage in Nepal. One useful model could be the Independent Power Producers' Association, Nepal (IPPAN) (IPPAN 2020). This organization serves as a link between the private sector and government to encourage the hydropower sector in the country. It provides a platform for members to exchange ideas and knowledge on hydropower and accelerate the pace of development through sharing of expertise and resources. The IPPAN is strictly focused on hydropower, but its platform, or a similar organization, could also be used to support capacity-building of energy storage professionals.

An alternative to privately led organizations such as the IPPAN could be a new government agency focused on energy storage. In the United States, the state of New York created the New York State Energy Research and Development Authority (NYSERDA), a state agency tasked with, inter alia, promoting the energy storage market. NYSERDA is responsible for allocating state funds to implement storage incentive programs and serves as the clearinghouse for information on incentives and technical resources for installing and operating energy storage facilities, opportunities for researchers and manufacturers to develop new energy storage technologies, and the state's progress toward its clean energy goals. NYSERDA also connects technical experts through one-on-one consultations for developers and contractors to help with project siting, sizing, and economics (NYSERDA 2020).

While these types of government or private organizations are not necessary for energy storage deployment, they can play an important role in raising the profile of energy storage opportunities and accelerating the adoption of appropriate storage solutions. This is particularly important in Nepal where there are no utility-scale energy storage projects to date and experience among policy makers, regulators, developers, and the general public alike is limited.

\section{Domestic Industrial Policy Supports Storage Manufacturing}

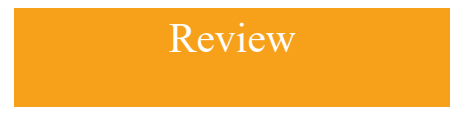

Nepal's Industrial Policy 2011 includes “energy-oriented industries" among a list of 10 prioritized sectors (Government of Nepal 2011). While there are no specific policies geared toward domestic manufacturing of energy storage technologies, this designation allows access to various tax incentives for industries related to energy production. Promoting the entire supply chain for energy storage technologies, including local manufacturing and assembly for storage components and trained technicians and staff for after-sales service, is a key step in developing an enabling ecosystem for storage deployment.

Scaling up domestic production of energy storage products, particularly battery storage, could support expanded use of storage in utility-scale applications as well as off-grid systems. Within the Ministry of Energy, Water Resources and Irrigation, the Alternative Energy Promotion 
Centre is responsible for developing commercially viable alternative energy industries in the country (AEPC 2021). These efforts are specifically targeted to improve energy access using renewable energy in rural populations. There are several private companies involved in this sector that combine battery storage with solar PV systems to provide energy access in remote areas. More recently, developers have proposed combining battery storage with micro-hydro projects to improve system reliability when hydropower resources fluctuate. Domestic production of battery storage systems in Nepal could reduce costs and accelerate the uptake of batteries for such applications.

\section{Targeted Support to Early Adopters}

The primary form of public support for utility-scale storage in Nepal is indirect support for highly impactful projects. In 2014, the Department of Electricity Development supported the development of the Sunkoshi-II (1,110 MW) and Sunkoshi-III (536 MW) PSH projects by undertaking the Detailed Project Report to evaluate the projects' feasibility (Kathmandu Post 2014). More recently, the government is supporting the NEA in the development of a pilot pumped storage project (MOEWRI 2018a).

Once developed, this project will be the country's first utility-scale storage project. The government directed the NEA to undertake the project, allowing the NEA to recover the project costs through its regulated tariff. This support strategy has several key benefits. First, by undertaking the feasibility studies, the government reduces the risks and costs for project developers to identify economically and technically feasible projects. Second, it reduces the risk for lending institutions to finance the project because the NEA has a cost recovery mechanism in place. And third, it enables the country to gain valuable experience developing and operating a PSH plant to learn more about the economic potential for utility-scale storage technologies in the power system.

An alternative method of support for storage technologies is through direct financial incentives such as grants, investment-based tax credits, and production-based incentives. The Alternative Energy Promotion Centre has such a program for investments used in rural applications through its RE Subsidy Program (MPE 2016).

This program subsidizes the cost of renewable energy projects - including the cost of battery storage - serving customers with no or unreliable grid connections, prioritizing technology solutions that provide energy at least cost. Direct financial incentives could be applied to utilityscale storage projects as well. Production-based incentives, either tax credits or feed-in tariffs, can improve project economics with a focus on developing areas with high resource potential.

Targeted government support can help bridge the funding gap and reduce risk for new storage technologies to reach commercial maturity. Support programs that are technology agnostic, focused on desired capabilities rather than specific technologies, can encourage a wider range of possible storage solutions. 


\subsection{Regulation}

The establishment of the ERC is prompting a host of regulatory reforms for Nepal's electric power sector. However, both existing and proposed regulations restrict storage-particularly nonhydro storage - from providing services or earning revenue for those services. These rules present a barrier to identifying and maximizing the cost-effective value of storage investments.

\section{Utilities and Private Developers Allowed To Make Storage Investments}

Rules defining ownership of energy storage technologies and criteria to obtain a license to provide grid services are defined in the Electricity Act (Government of Nepal 1992). These rules allow utilities and IPPs to invest in PSH plants, but other stand-alone storage technologies do not qualify to obtain a license as a generation or transmission asset. The Department of Electricity Development only lists hydro, thermal, solar, wind, biomass, co-generation, and transmission among its categories of licensees for the power sector.

For prospective developers of nonhydro energy storage projects, there is no clear mechanism to legally own and operate a storage project connected to the national grid. However, these rules do not prevent entities that already have a generation or transmission license from investing in energy storage technologies as part of their technology portfolio to provide grid services.

The ERC is in the process of revising the country's regulatory framework with an updated grid code. However, under the Draft Grid Code currently proposed, nonhydro energy storage technologies would still not qualify to obtain a generation or transmission license. Expanding the definition of a grid asset to allow investments in all energy storage technologies from any type of developer can increase the investment potential of energy storage technologies in the country.

\section{Interconnection Processes Give Storage the Right To Interconnect and Obtain Transmission Service}

\section{Review}

Under the Electricity Act, there is no clearly defined process or criteria for obtaining transmission access. In its Draft Grid Code intended to replace the Electricity Act, the ERC presents a detailed Connection Code that outlines the technical and operational criteria as well as the application process for any users seeking to connect to the transmission system. While most of the Connection Code is focused on connection requests from generation, transmission, and distribution licensees, there are provisions for "other users."

If stand-alone storage cannot qualify as in one of the former categories, it could fall into this latter group of "other users." Under this provision, applicants must submit standard planning data to allow the grid operator to carry out any necessary studies to assess the impact of the proposed connection to the grid. Applicants are required to pay the costs for facilities required to connect to the grid, including any grid impact studies from the system planner, and all applications are to be processed within 90 days. 
The proposed Connection Code supports a range of possible storage solutions, including mechanical, electrochemical, and thermal storage technologies. Additional steps could further expedite interconnection approvals for storage projects. For example, under current rules, prospective users can request that the grid operator provide them with relevant data and information about the technical parameters of the grid to inform their project planning. The grid operator could go a step further by publishing a network map of preferred storage locations or allowing expedited approval for projects with low anticipated negative impacts on the grid to incentivize storage investments in areas that support the grid.

\section{Promotion of High-Quality Standardized Energy Storage Technologies Through Safety Standards}

Review

There are currently no safety standards and procedures in place for energy storage technologies in Nepal. The lack of standards is not limited to energy storage. Others have noted the lack of standardization in operation and maintenance procedures for hydropower plants have led to poor plant performance and safety concerns (Khan 2019). The IPPAN has taken up the issue of improving safety and maintenance standards and procedures for the hydropower sector, including PSH technologies (IPPAN 2020).

These efforts by the IPPAN could be broadened to include other energy storage technologies. For example, the Indian Energy Storage Alliance is collaborating with UL to create an Energy Storage Standards Taskforce. The taskforce is working on raising awareness about the standards development process, identifying gaps in existing standards, and serving as a leader in forming new standards to fill these gaps. The Indian Energy Storage Alliance is also working within the government as a member of the Bureau of Indian Standards' Energy Storage Sectional Committee. The committee's efforts are focused on standardization in the field of grid integration of electrical energy storage systems.

As interest in energy storage technologies in Nepal grows, increased education, training, and technical support for the development of new codes, standards, and regulations will be critical for the safe and timely deployment of these technologies.

\section{Operating Requirements for Fast-Responding Assets}

Updates to the electricity grid code are aimed at enabling the system to better respond to unexpected deviations. These include requirements for large generators to be fitted with automatic generation control and able to increase their output at least $5 \%$ over their maximum continuous rating for up to five minutes (ERC 2020b).

Other regulatory efforts to increase fast-moving assets have focused on ancillary service requirements. Nepal's ancillary services sector is still in the development phase. The following table summarizes the various ancillary service products proposed by the ERC. 
Table 6. Fast Response Ancillary Services Under Development

\begin{tabular}{|c|c|c|c|c|c|}
\hline & $\begin{array}{l}\text { Primary } \\
\text { Frequency } \\
\text { Regulation }\end{array}$ & $\begin{array}{l}\text { Secondary } \\
\text { Frequency } \\
\text { Regulation }\end{array}$ & $\begin{array}{l}\text { Spinning } \\
\text { Reserve }\end{array}$ & $\begin{array}{l}\text { Backup } \\
\text { Reserve }\end{array}$ & Black Start \\
\hline Signal & Automatic & Automatic & System Operator & $\begin{array}{l}\text { System } \\
\text { Operator }\end{array}$ & $\begin{array}{l}\text { System } \\
\text { Operator }\end{array}$ \\
\hline Quantity & Not specified & Not specified & \multicolumn{2}{|c|}{$\begin{array}{l}\text { Largest synchronized unit or largest } \\
\text { power import source }\end{array}$} & Not specified \\
\hline $\begin{array}{l}\text { Response } \\
\text { time }\end{array}$ & $\begin{array}{l}0-5 s ; \text { fully } \\
\text { available by } \\
25 s\end{array}$ & $\begin{array}{l}25-30 \text { s with } 30- \\
\text { min duration }\end{array}$ & Not specified & $\begin{array}{l}5 \text { min with 8-hr } \\
\text { duration }\end{array}$ & $\begin{array}{l}\text { Immediate } \\
\text { upon request }\end{array}$ \\
\hline $\begin{array}{l}\text { Provided } \\
\text { by }\end{array}$ & $\begin{array}{c}\text { Conventional } \\
\text { large } \\
\text { generators }\end{array}$ & $\begin{array}{l}\text { All conventional } \\
\text { generators }\end{array}$ & $\begin{array}{l}\text { Generators } \\
\text { synchronized to } \\
\text { the grid }\end{array}$ & $\begin{array}{c}\text { Generators } \\
\text { with fast-start } \\
\text { capability }\end{array}$ & $\begin{array}{l}\text { Strategically } \\
\text { located } \\
\text { generating } \\
\text { plants }\end{array}$ \\
\hline Status & Proposed & Proposed & Proposed & Proposed & Proposed \\
\hline
\end{tabular}

Under the proposed rules, all generators synchronized to the grid are required to provide spinning reserves, and all conventional generators are required to provide primary and secondary frequency regulation. Generators are not compensated for providing ancillary services; the costs are included as part of the regulated tariff or power purchase agreement (PPA). Notably, under current regulations, PSH is the only storage technology eligible to provide ancillary services.

The ERC's proposed ancillary service requirements mark a positive advancement in improving system flexibility in Nepal. Further updates to set a requirement for the desired amount of ancillary services required to maintain reliable power supplies and establish a separate payment for providing those services can signal investment needs among project developers. And expanding the range of technologies eligible to provide these services to include energy storage technologies can increase the amount of fast-responding assets available to meet these needs.

\section{Electricity Service Charges Reflect the Value of and Increase Price Transparency for Energy Services}

Review

Electricity tariffs and generation contract prices in Nepal are increasingly capturing the value of electricity services to the grid. This is an important step toward incentivizing investments in technologies that best fit the needs of the system. For instance, almost all tariffs for consumer groups connected at the medium and high voltage levels have a seasonal and time of day electricity tariff, encouraging load shifting away from dry season months and peak demand hours when the system experiences supply constraints. ${ }^{10}$ Figure 6 shows the variation in energy

\footnotetext{
${ }^{10}$ Nondomestic, recreational business, and community wholesale consumers connected at the medium voltage level have fixed demand and energy tariffs with no seasonal or time-of-day component.
} 
charges (NPR per kWh) across seasons and time of day, averaged over all relevant consumer groups (ERC 2020a).

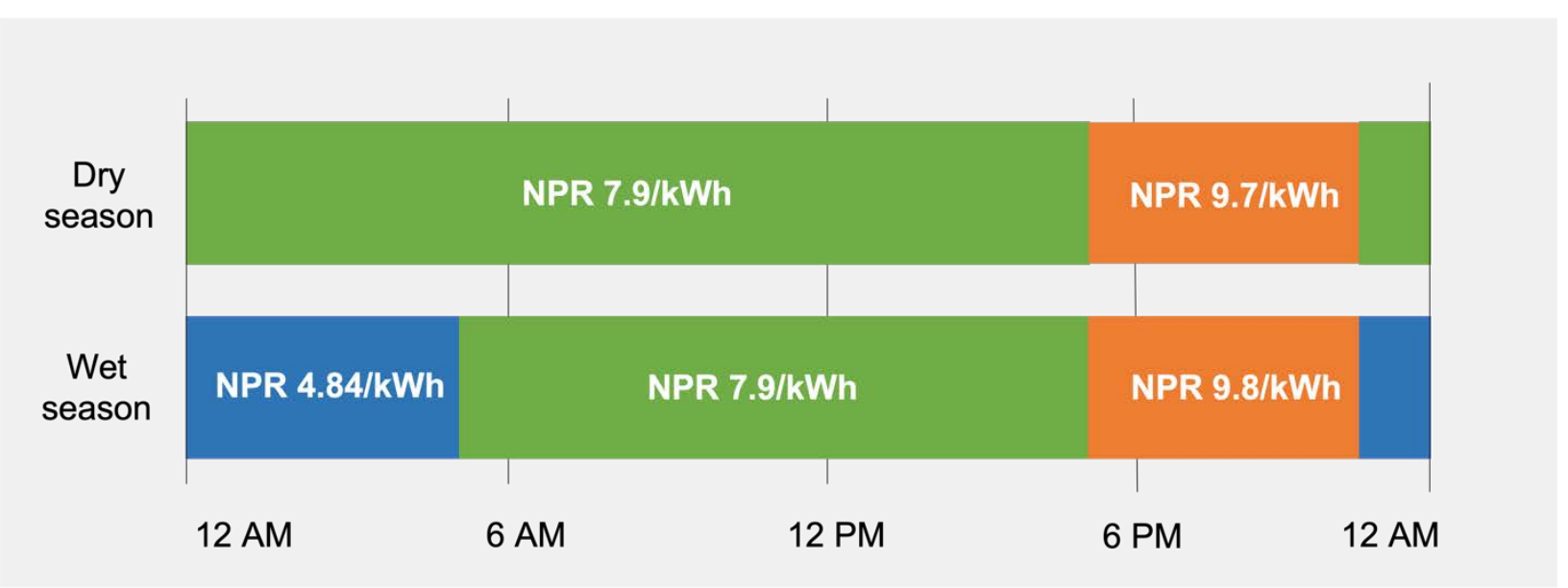

Figure 6. Seasonal and time-of-day variation in electricity tariffs averaged for all eligible mediumand high-voltage consumer groups

Similarly, the power purchase rates from NEA to IPP hydropower projects include a seasonal and time-of-day component to encourage generators to be available when needed during peak hours and dry season months (Table 7).

Table 7. Seasonal and Time-of-Day PPA Rates (NPR per kWh) for Hydropower Plants

Source: Adapted from NEA 2017a

\begin{tabular}{l|c|c|cc}
\hline Plant Type & Wet Season & \multicolumn{2}{c}{$\begin{array}{c}\text { Dry Season } \\
\text { Peak hours }\end{array}$} & Nonpeak hours \\
\hline ROR & 4.8 & \multicolumn{2}{|c|}{8.4} & $\begin{array}{c}\text { Min. Dry Season Energy } \\
\text { PROR }\end{array}$ \\
\hline Storage & 4.8 & $8.5-10.55^{*}$ & 8.4 & $30 \%$ \\
\hline
\end{tabular}

${ }^{*}$ Rate varies based on number of hours plant can generate at rated capacity (1-6 hours)

${ }^{*}$ If wet season energy exceeds $50 \%$ annual energy, this rate is decreased by the percentage in excess of $50 \%$

These contract prices incentivize hydropower generators to maximize available energy during dry season months when supplies are low and, in the case of PROR plants, expand the available peaking capacity during this season. These pricing mechanisms could be expanded to other technologies to attract investments with the desired availability and performance to meet system needs.

Tariff reforms for ancillary services could also improve system performance. Ancillary services are currently provided from hydropower plants with no compensation. As a result, generators have no incentive to improve the speed and accuracy with which these resources respond. Updating the price signals to reward fast-ramping resources, such as energy storage, could lower total ancillary service requirements. 


\section{Storage Able To Compete with Other Grid Assets To Provide Multiple Services}

Under existing regulations and the ERC Draft Grid Code, PSH is the only stand-alone energy storage technology that can qualify as a generation asset to provide energy and ancillary services (Government of Nepal 1992; ERC 2020b). Other technologies, such as battery storage, do not qualify as "generating units" and, as a result, cannot provide energy or ancillary services. Energy storage technologies could potentially qualify as transmission assets if they fall under the ERC's definition of "electrical equipment" owned and operated by the grid operator for the purpose of transmitting electricity (ERC 2020b).

While existing regulations limit the use of nonhydro stand-alone energy storage, the NEA and IPPs could potentially develop hybrid plants that include energy storage to meet energy and ancillary service needs. For example, battery storage paired with an ROR plant could be used to meet peak demand or frequency regulation requirements. These applications would require careful monitoring of the state of charge for the storage facility to ensure the system is available when needed.

Energy storage is technically capable of providing a range of grid services, but existing regulations restrict the use of nonhydro technologies. Expanding the range of technologies eligible to provide grid services could enable the identification of cost-effective technologies best suited to meet system needs.

\section{Storage Able To Receive Revenue for Providing Multiple Services}

Revise

Being eligible to provide grid services is one aspect of establishing a fair playing field for energy storage. The other critical consideration is whether energy storage can be compensated for the value it provides to the grid. While the ERC has not established a rate structure for energy storage projects, the existing rate structure for NEA and IPP projects provide some insight into the types of compensation storage projects may receive. NEA-owned projects are remunerated under cost-of-service regulation overseen by the ERC. Therefore, there is no direct compensation for specific projects or specific services; NEA must use its own internal analysis to identify the appropriate mix of technologies to meet its needs.

IPP plants are compensated for energy only through their PPAs with the NEA. These agreements include incentives to maximize their generation during dry season months (see (NEA 2017a)). However, only PROR plants have a time-of-day tariff that encourages generators to provide peaking services. Rates for reservoir storage plants only vary by season and have no incentive to provide load following or peaking services. For energy storage technologies, a rate structure similar to that of PROR plants can encourage storage projects that meet system needs for diurnal load shifting and peak demand management.

In other cases, such as ancillary services, generators are required to provide these services but are not directly compensated for doing so. This has implications for the economic viability of nonhydro energy storage projects, as revenue from energy sales alone may not be sufficient to 
cover the costs of a stand-alone energy storage facility. It may also impact the performance of grid assets providing ancillary services because there is no investment incentive for technologies with superior speed and accuracy to meet ancillary service needs. Energy storage, with its ability to rapidly respond to control signals to inject or withdraw power, could improve system operations.

Revising existing compensation mechanisms to reflect the desired needs and capabilities of the system for a broader range of energy services, including energy, load following, peak management, and ancillary services, could improve the economic viability of suitable technologies, including energy storage, and improve overall grid performance.

\section{Guidelines for Policy Makers and Regulators}

The application of the Energy Storage Readiness Assessment for Nepal reveals technical and economic opportunities for energy storage to provide ancillary services and peak demand management. However, within the country's policy and regulatory frameworks, there are significant barriers to enabling storage projects to provide these services.

Nepal's existing energy policy does not lay out a clear vision for energy storage in the country. However, several activities are underway that can inform the development of clear policy framework for energy storage that addresses the many services that storage can provide as well as the full range of storage technologies available.

Having this framework in place can accelerate the identification and implementation of systemappropriate storage solutions. Nepal, like most countries, is in a familiarization stage with nonhydro energy storage technologies. Establishing a forum for knowledge exchange where stakeholders can find resources and share best practices can help with scale-up and replication of successful projects.

Integrating energy storage into national energy policies also enables regulatory authorities to begin implementing necessary regulations to achieve these policy outcomes. Chief among these in Nepal are regulations that enable energy storage to provide a wider range of grid services and accompanying compensation mechanisms - whether through regulated tariffs or markets - to earn revenue for those services.

The range of energy storage technologies for utility-scale grid applications is expanding quickly, including multiple forms of mechanical, electrochemical, and thermal energy storage. Policy makers and regulators can encourage technology innovation through technology-agnostic policies, programs, and rules focused on desirable characteristics and operating requirements rather than specific technologies. A technology-agnostic approach will avoid creating artificial barriers for emerging technologies.

As Nepal's power system continues to transform, energy storage technologies can contribute to meeting evolving system needs for flexibility and reliability. Comprehensive policy and regulatory frameworks can enable economically viable storage technologies to meet these needs. 


\section{References}

Adhikari, Prabal. 2018. “Operationalizing the Power Trading Company in Nepal.” November 5. https://energypedia.info/images/2/2b/Nepal_Power_Trading_Company_by_Mr_Prabal_A dhikari_NPTC.pdf.

AEPC. 2021. “Alternative Energy Promotion Centre.” 2021. https://www.aepc.gov.np/missionvision-and-strategy.

BNEF. 2019. "Battery Storage in India: Entering a Decade of Growth." BNEF (Bloomberg New Energy Finance).

Bowen, Thomas, Ilya Chernyakhovskiy, and Paul Denholm. 2019. "Grid-Scale Battery Storage: Frequently Asked Questions.” NREL/TP-6A20-74426. Golden, CO: National Renewable Energy Laboratory. https://www.nrel.gov/docs/fy19osti/74426.pdf.

CEA. 2020. "Report on Optimal Generation Capacity Mix for 2029-30.” Delhi: CEA (Cetral Electricity Authority).

http://cea.nic.in/reports/others/planning/irp/Optimal_mix_report_2029-30_FINAL.pdf.

CEN, and REPIC. 2019. "Proceedings of Lithium Battery Workshop." In Reliability of Lithium Batteries to Make Electric Vehicles More Energy Efficient. Kathmandu: CEN (Clean Energy Nepal), REPIC (Renewable Energy and Energy Efficiency Promotion in International Cooperation). https:/www.repic.ch/wp-content/uploads/2020/07/LithiumBattery-Proceedings-Final-Workshop.pdf.

CERC. 2017. "Staff Paper on Introduction of Electricity Storage System in India." Delhi: Central Electricity Regulatory Commission. http://www.cercind.gov.in/2017/draft_reg/SP.pdf.

Chernyakhovskiy, Ilya, Mohit Joshi, David Palchak, and Amy Rose. 2021. "Energy Storage in South Asia: Understanding the Role of Grid-Connected Energy Storage in South Asia's Power Sector Transformation.” Golden, CO: National Renewable Energy Laboratory. https://www.nrel.gov/docs/fy21osti/79915.pdf .

Dixit, Kunda. 2018. "Nepal Turns to Solar and Batteries to Meet Peak Demand." Nepali Times, August 3, 2018. https://www.nepalitimes.com/here-now/nepal-turns-to-solar-andbatteries-to-meet-peak-demand/.

ERC. 2020a. Determination of Electricity Tariff Rate of Consumers of Nepal Electricity Authority. www.erc.gov.np.

. 2020b. Nepal Grid Code (DRAFT).

ESMAP. 2019. "Nepal: Beginning Reforms and Ending Power Outages.” Energy Subsidy Reform Facility (ESRF). ESMAP. http://documents1.worldbank.org/curated/en/725071569924093474/pdf/Nepal-EnergySubsidy-Reform-Facility.pdf.

ET Energy World. 2020. "Power Min Proposes RPO for Found the Clock Renewable Energy," August 29, 2020. https://energy.economictimes.indiatimes.com/news/renewable/powermin-proposes-rpo-for-round-the-clock-renewable-energy/77815431.

Government of Nepal. 1984. Nepal Electricity Authority Act, 2041 (1984).

https://moewri.gov.np/storage/listies/May2020/nepal-electricity-authority-act-20411984.pdf. . 1992. Electricity Act, 2049 (1992). https://www.lawcommission.gov.np/en/archives/12917. 2011. Industrial Policy, 2011. www.lawcommission.gov.np. . 2017. Electricity Regulation Commission Act, 2074. https://erc.gov.np/storage/listies/April2020/erc-act-2017-english.pdf. 
Gupta, Uma. 2019. "SECI Tenders 400 MW of Renewables with Storage Option." https://www.pv-magazine-india.com/2019/10/18/seci-tenders-400-mw-of-hybrid-solarwith-storage-option/.

Himalayan News Service. 2020. "Dhalkebar Substation Charged at Full Capacity." https://thehimalayantimes.com/business/dhalkebar-substation-charged-at-full-capacity.

IEA. 2018. "Electricity Consumption." IEA. www.iea.org/statistics. . 2020. "India 2020 Energy Policy Review."

IESA. 2019. “Energy Storage System: Roadmap for India: 2019-2032.” IESA (India Energy Storage Alliance). https://indiasmartgrid.org/reports/ISGF_Report_Energy_Storage_System_RoadmapforIn dia_2019to2032_11July2019_Draft.pdf.

IPPAN. 2020. “Independent Power Producers' Association, Nepal.” 2020. http://www.ippan.org.np/page/objectives.

Kathmandu Post. 2014. "Sunkoshi II, III to Be Developed as Pumped-Storage." Kathmandu Post, January 12, 2014. https://kathmandupost.com/money/2014/01/12/sunkoshi-ii-iii-tobe-developed-as-pumped-storage.

Khan, Barbar. 2019. "Bringing Industry Standards to Nepal's Hydropower Sector." International Water Power \& Dam Construction, June 7, 2019. https://www.waterpowermagazine.com/features/featurebringing-industry-standards-tonepals-hydropower-sector-7248819/.

Maloney, Peter. 2017. "ConEd, NRG Partner on 4MWh Mobile Battery Storage Demo for REV Docket.” UtilityDive, March 1, 2017. https://www.utilitydive.com/news/coned-nrgpartner-on-4-mwh-mobile-battery-storage-demo-for-rev-docket/437125/.

Ministry of Finance. 2020. “Economic Survey 2019/20.” Singh Durbar, Kathmandu: Government of Nepal.

https://mof.gov.np/uploads/document/file/Economic\%20Survey\%202019_202011250241 53.pdf.

MOEWRI. 2018a. "White Paper on Energy, Water Resources and Irrigation Sector's Current Status and Roadmap for Future." Kathmandu: Government of Nepal, Ministry of Energy, Water Resources, \& Irrigation.

- 2018b. "National Energy Efficiency Strategy, 2075." Ministry of Energy, Water Resources and Irrigation, Government of Nepal. https://www.moewri.gov.np/storage/listies/May2020/national-energy-efficiency-strategy2075-en.pdf.

Mongird, K., V. Viswanathan, P. Balducci, J. Alam, V. Fotedar, V. Koritarov, and B. Hadjerioua. 2019. "Energy Storage Technology and Cost Characterization Report." PNNL-28866. Pacific Northwest National Laboratory, Argonne National Laboratory, Oak Ridge National Laboratory. https://energystorage.pnnl.gov/pdf/PNNL-28866.pdf.

MPE. 2016. Renewable Energy Subsidy Policy, 2073 BS. https://www.aepc.gov.np/uploads/docs/2018-06-

19_RE\%20Subsidy\%20Policy,\%202073\%20(English).pdf.

NEA. 2017a. "NEA Board Decision on the Power Purchase Rates and Associates Rules for PPA of ROR/PROR/Storage Projects Effective from 2074/01/14 (April 27, 2017).” Kathmandu: NEA (Nepal Electricity Authority). https://www.nea.org.np/admin/assets/uploads/supportive_docs/99343289.pdf. 
. 2017b. "Nepal Electricity Authority A Year in Review - Fiscal Year 2016/2017."

Durbar Marg, Kathmandu: NEA (Nepal Electricity Authority).

. 2018. "Nepal Electricity Authority A Year in Review - Fiscal Year 2017/2018." Durbar

Marg, Kathmandu: NEA (Nepal Electricity Authority).

. 2019a. "Transmission/Project Management Directorate." Kathmandu: NEA (Nepal

Electricity Authority).

https:/www.nea.org.np/admin/assets/uploads/annual_publications/Grid_2076.pdf.

. 2019b. "Nepal Electricity Authority A Year in Review - Fiscal Year 2018/2019."

Durbar Marg, Kathmandu: NEA (Nepal Electricity Authority).

. 2020a. "Corporate Development Plan 2018/19 - 2022/23." Kathmandu: NEA (Nepal

Electricity Authority).

—. 2020b. "Nepal Electricity Authority A Year in Review - Fiscal Year 2019/2020."

Durbar Marg, Kathmandu: NEA (Nepal Electricity Authority).

Nepal Energy Forum. 2017. "Battery Import Dwindles as Load-Shedding Ends." Nepal Energy

Forum, December 30, 2017. http://www.nepalenergyforum.com/battery-import-

dwindles-as-load-shedding-ends/.

New Business Age. 2021. "NEA Gets Permission for Surveying Kulekhani-Sisneri Pump

Storage,” March 26, 2021. https://www.newbusinessage.com/Articles/view/13213.

NYSERDA. 2020. "New York State Energy Research and Development Authority

(NYSERDA).” 2020. https://www.nyserda.ny.gov.

Open Data Nepal. n.d. "Electricity Load Profile of Nepal in 2073: Nepal Electricity Authority." Database. Accessed July 26, 2021. https://opendatanepal.com/dataset/electricity-loadprofile-of-nepal-in-2073-nepal-electricity-authority.

Renewable Energy World. 2016. "Nepal, Bangladesh Agree to Build More Than 1,600 MW of Pumped-Storage Hydropower.” Renewable Energy World, October 25, 2016.

https://www.renewableenergyworld.com/storage/nepal-bangladesh-agree-to-build-morethan-1-600-mw-of-pumped-storage-hydropower/\#gref.

Rose, Amy, Ilya Chernyakhovskiy, David Palchak, Sam Koebrich, and Mohit Joshi. 2020.

"Least-Cost Pathways for India's Electric Power Sector." NREL/TP-6A20-76153.

Golden, CO: National Renewable Energy Laboratory.

https://www.nrel.gov/docs/fy20osti/76153.pdf.

Rose, Amy, Sam Koebrich, David Palchak, Ilya Chernyakhovskiy, and Claire Wayner. 2020. "A Framework for Readiness Assessments of Utility-Scale Energy Storage." NREL/TP6A20-78197. Golden, CO: National Renewable Energy Laboratory.

https://www.nrel.gov/docs/fy21osti/78197.pdf.

RPGCL. 2018. "Transmission System Development Plan of Nepal." Government of Nepal, Ministry of Energy, Water Resources, \& Irrigation.

https://nepalindata.com/media/resources/items/15/bTransmission-System-DevelopmentPlan-of-Nepal.pdf.

Water and Energy Commission Secretariat. 2017. "Electricity Demand Forecast Report." Government of Nepal. https://www.moewri.gov.np/storage/listies/May2020/electricitydemand-forecast-report-2014-2040.pdf.

Zinaman, Owen, Thomas Bowen, and Alexandra Aznar. 2020. "An Overview of Behind-theMeter Solar-Plus-Storage Program Design: With Considerations for India." NREL/TP7A40-74131. Golden, CO: National Renewable Energy Laboratory. https://www.nrel.gov/docs/fy20osti/74131.pdf. 